Key Words: Spent Fuel Cladding, Spent Fuel Cladding Analysis, Spent Fuel Cladding Chemistry

Retention: Permanent

\title{
ANALYSIS OF CLADDING RESIDUES FROM THE DISSOLUTION OF IRRADIATED DRESDEN-1 REACTOR FUEL
}

\author{
G. F. Kessinger
}

March 31, 2004 
This document was prepared in conjunction with work accomplished under Contract No. DE-AC09-96SR18500 with the U. S. Department of Energy.

\section{DISCLAIMER}

This report was prepared as an account of work sponsored by an agency of the United States Government. Neither the United States Government nor any agency thereof, nor any of their employees, makes any warranty, express or implied, or assumes any legal liability or responsibility for the accuracy, completeness, or usefulness of any information, apparatus, product or process disclosed, or represents that its use would not infringe privately owned rights. Reference herein to any specific commercial product, process or service by trade name, trademark, manufacturer, or otherwise does not necessarily constitute or imply its endorsement, recommendation, or favoring by the United States Government or any agency thereof. The views and opinions of authors expressed herein do not necessarily state or reflect those of the United States Government or any agency thereof.

This report has been reproduced directly from the best available copy.

Available for sale to the public, in paper, from: U.S. Department of Commerce, National Technical Information Service, 5285 Port Royal Road, Springfield, VA 22161, phone: (800) 553-6847, fax: (703) 605-6900

email: orders@ntis.fedworld.gov

online ordering: http://www.ntis.gov/help/index.asp

Available electronically at http://www.osti.gov/bridge

Available for a processing fee to U.S. Department of Energy and its contractors, in paper, from: U.S. Department of Energy, Office of Scientific and Technical Information, P.O. Box 62, Oak Ridge, TN 37831-0062,

phone: (865)576-8401,

fax: (865)576-5728

email: $\underline{\text { reports@ adonis.osti.gov }}$ 


\section{Table of Contents}

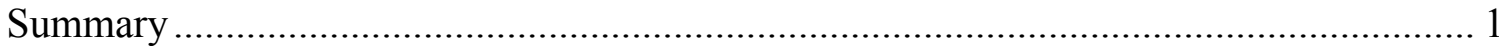

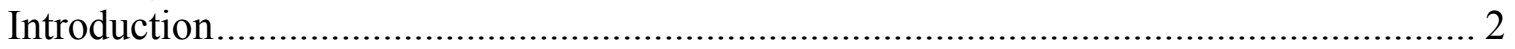

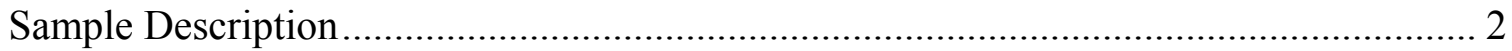

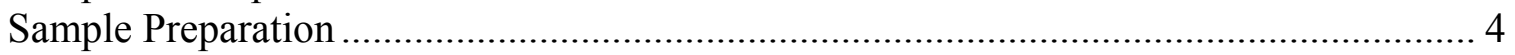

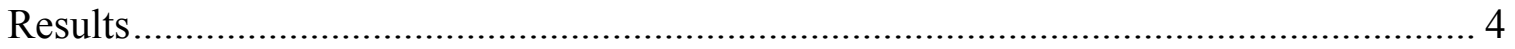

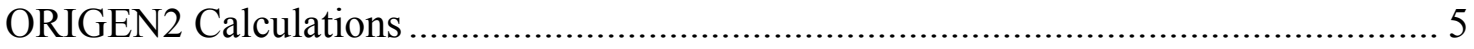

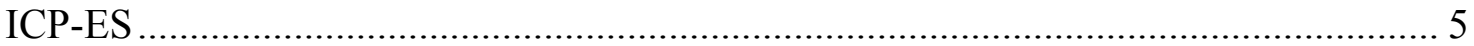

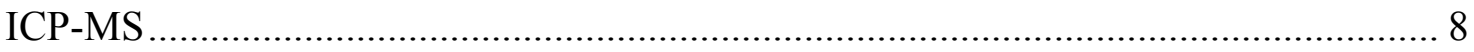

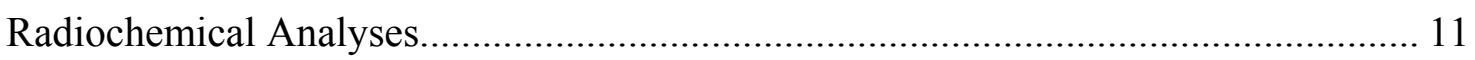

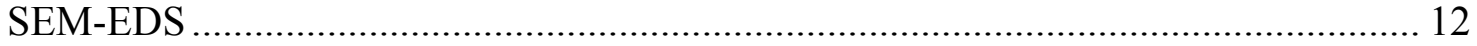

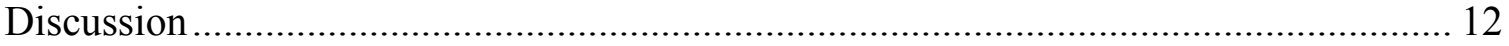

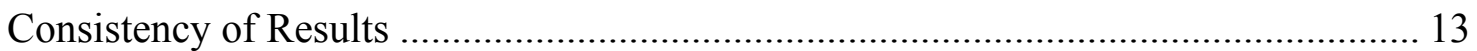

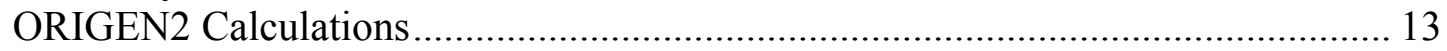

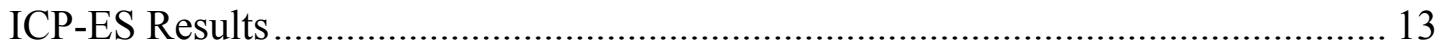

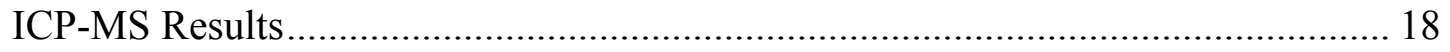

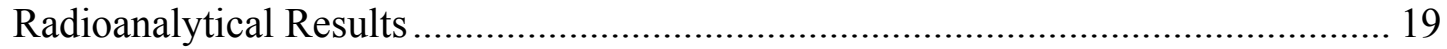

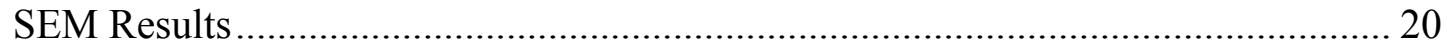

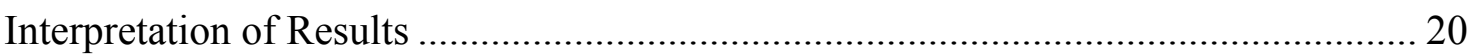

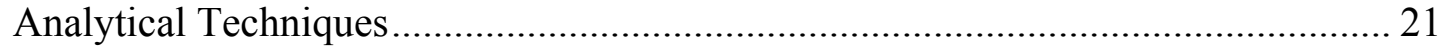

Fuel/Cladding Chemistry …………………………...................................... 22

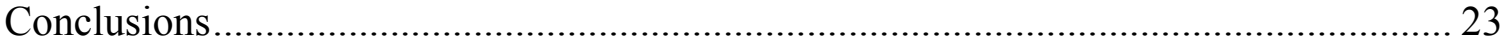

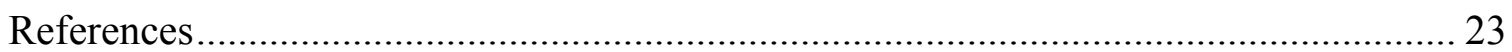

\section{Table of Figures}

Figure 1. Photograph (taken through remote cell window) of as-received Dresden reactor

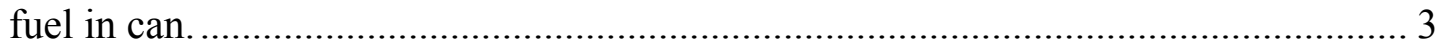

Figure 2. Photographs of cladding (after fuel meat dissolution) taken through cell

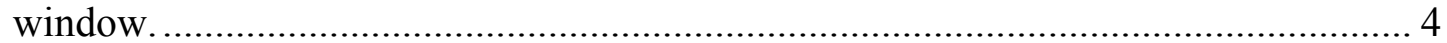

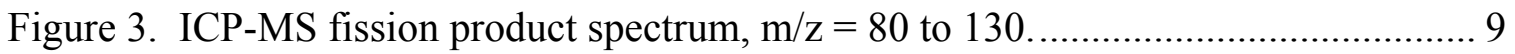

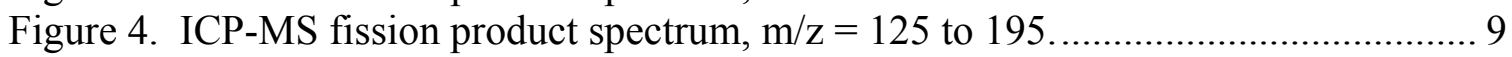

Figure 5. ICP-MS actinide spectrum, $\mathrm{m} / \mathrm{z}=229.5$ to 255 , low sensitivity. The dual traces are due to different dilutions of the sample (the more intense signal is due to a

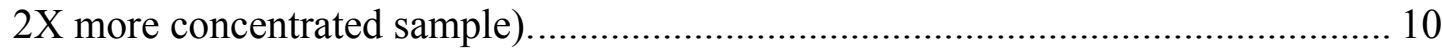

Figure 6. ICP-MS actinide spectrum, $\mathrm{m} / \mathrm{z}=229.5$ to 252 , high sensitivity. ……........... 10

Figure 7. Emitted electron image of as-received cladding slice, 40x magnification....... 14

Figure 8. Back scattered electron image of the surface of the as-received slice of

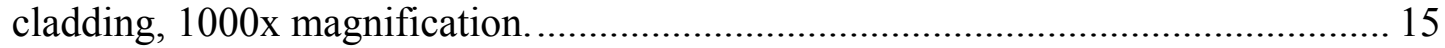

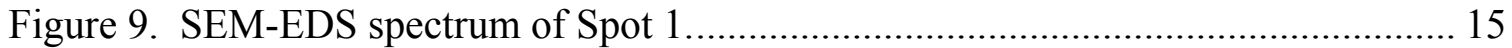

Figure 10. The EDS spectrum of Spot 2............................................................... 16

Figure 11. Electron emission image of surface of as-received sample at Spots 3 and 4, 200x magnification. The bright spots in this image indicate the topography (high spots) on the sample surface................................................................................ 16

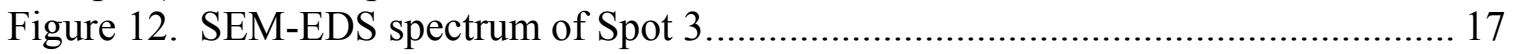




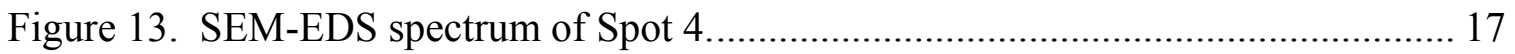

\section{Table of Tables}

Table 1. ORIGEN2-generated Predictions for Fission Product and Actinide Content in

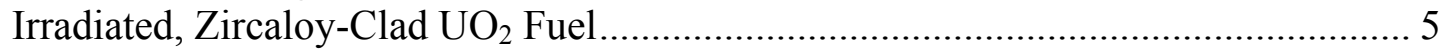

Table 2. ICP-ES Results for Dresden-1 SNF Zircaloy 2 Cladding................................. 6

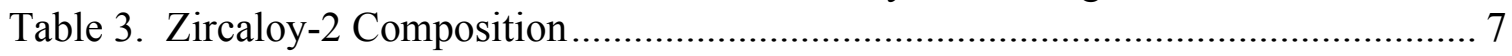

Table 4. Expected Elemental Ratios for Zircaloy-2 ................................................ 7

Table 5. Computed Elemental Ratios for Dresden-1 Zircaloy-2 Cladding ...................... 7

Table 6. Actual and Predicted Maximum Analyte Abundances in Dresden-1 Cladding . 8

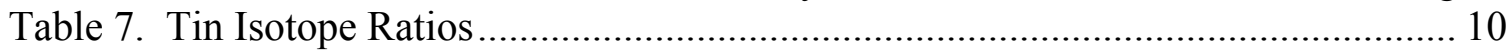

Table 8. Averaged ICP-MS Actinide Results for Dresden-1 Zircaloy-2 Cladding ......... 10

Table 9. Radiochemical Results for Dresden-1 Zircaloy-2 Cladding ............................ 11 


\section{Summary}

The primary goal of this work was to evaluate the efficacy of the chop-leach spent fuel dissolution process, with nitric acid dissolvent, for removing actinides and fission products from Zircaloy cladding to produce a cladding capable of meeting low-level waste (LLW) disposal criteria. Analysis of the cladding shows that actinides are present in the cladding at concentrations in the range $5000-40,000 \eta \mathrm{Ci} / \mathrm{g}$, which is 50 to 400 times greater than the acceptable TRU limit in LLW.

It appears that the nitric acid used for dissolution (initial concentration $4 \underline{\mathrm{M}}$, with $10 \underline{\mathrm{M}}$ added as the dissolution proceeded) was inadequate for solubilizing the fuel meat. Scanning electron micrographs of the as-sampled cladding surface showed particles of material high in $\mathrm{U}$ on the surface of the cut samples, suggesting the fuel meat was not completely dissolved. If the cladding is to meet LLW disposal limits, it is likely that a more robust chemical treatment will be required to more completely digest the fuel meat. 


\section{Introduction}

Head-end processing of spent nuclear reactor fuel (SNF) to prepare it for separation of fissile material from fission products and inert materials has been practiced for six decades and the experimental techniques have been discussed by numerous investigators over the past five decades. ${ }^{1,2,3,4}$ The work reported within describes analyses of spent fuel cladding recovered subsequent to the laboratory scale chop-leach processing of irradiated Zircaloy 2-clad uranium dioxide $\left(\mathrm{UO}_{2}\right)$ fuel. The primary goal of the present study is to determine the efficacy of the chop-leach process, using $\mathrm{HNO}_{3}$ as the dissolvent, for the removal of fission products and actinides from Zircaloy cladding. If the nitric acid treatment adequately leaches actinides from the Zircaloy cladding, the radionuclide content of the cladding could meet low-level radioactive waste (LLW) criteria; however, if the transuranic element (TRU) content in the cladding were greater than 100 nanoCuries of TRU per gram of cladding $(\eta \mathrm{Ci} / \mathrm{g})$, the cladding would be classified as a TRU waste or high-level waste (HLW). The LLW versus TRU waste (or HLW) issue is significant because of cost and difficulty associated with TRU waste and HLW disposal.

\section{Sample Description}

The sample of Dresden spent fuel used in this study, with a burn-up 23,480 MWday/t, was discharged from the Dresden-1 Reactor, Morris, IL, on September 1, 1975. It was transferred to Savannah River Site from Oak Ridge National Laboratory in the late 1970's in support of the Consolidated Fuel Reprocessing Program. The fuel rods were sheared to expose the $\mathrm{UO}_{2}$ before arriving at the Savannah River Technology Center. The physical appearance of the fuel before dissolution is shown in Figure 1.

The fuel was dissolved in three batches using hot $\mathrm{HNO}_{3}$. Mixing was accomplished by solution convection and the bubbling of gas from the reaction of the fuel meat and acid (although it was possible to sparge the solution, it did not appear to be necessary to do so). Initially, the dissolver was charged with $\sim 1 \mathrm{~L}$ of $4 \mathrm{M} \mathrm{HNO}_{3}$, to which the basket containing the fuel was introduced. Reaction of the fuel with the acid was immediate, and the generation of $\mathrm{NO}_{2}$ vapor (hereafter referred to as "brown vapor") was easily observable through the cell window. The temperature increase due to addition of the solution was generally quite modest. Ambient temperatures in the cell were around $30^{\circ} \mathrm{C}$ and the maximum temperatures after fuel addition (but before heating) were near $40^{\circ} \mathrm{C}$. Once the temperature increase ceased, the dissolver was heated and $10 \underline{\mathrm{M}} \mathrm{HNO}_{3}$ was added to the mixture. Using the combination of the heat produced during the exothermic dissolution reaction and the heating mantle, the temperature was increased to $\sim 90^{\circ} \mathrm{C}$. The amount of $10 \underline{\mathrm{M}}$ acid added was determined by estimating the amount of acid required to completely dissolve the $\mathrm{UO}_{2}$ and produce a product $\sim 1.5 \underline{\mathrm{M}}$ in $\mathrm{H}^{+}(\mathrm{aq})$ and over $400 \mathrm{~g} / \mathrm{L} \mathrm{U},{ }^{\mathrm{i}}$ based on the chemical reaction:

\footnotetext{
${ }^{\mathrm{i}}$ It was necessary to meet these $\left[\mathrm{H}^{+}\right]$and $[\mathrm{U}]$ goals so the dissolver product could be diluted to meet the feed requirements for the solvent extraction process, $\sim 1 \mathrm{M} \mathrm{H}^{+}$and $\sim 300 \mathrm{~g} / \mathrm{L} \mathrm{U}$.
} 


$$
\mathrm{UO}_{2}(\mathrm{~s})+4 \mathrm{HNO}_{3}(\mathrm{aq})=\mathrm{UO}_{2}\left(\mathrm{NO}_{3}\right)_{2}(\mathrm{aq})+2 \mathrm{NO}_{2}(\mathrm{~g})+2 \mathrm{H}_{2} \mathrm{O}(\mathrm{l}) .^{5}
$$

The addition rate for acid was based on the temperature of the reaction vessel (the desire was to keep $\mathrm{T} \approx 90^{\circ} \mathrm{C}$ ) and the opacity of the brown vapor in the dissolver. When leaching of the $\mathrm{UO}_{2}$ from the cladding was believed complete, the dissolver solution was pumped

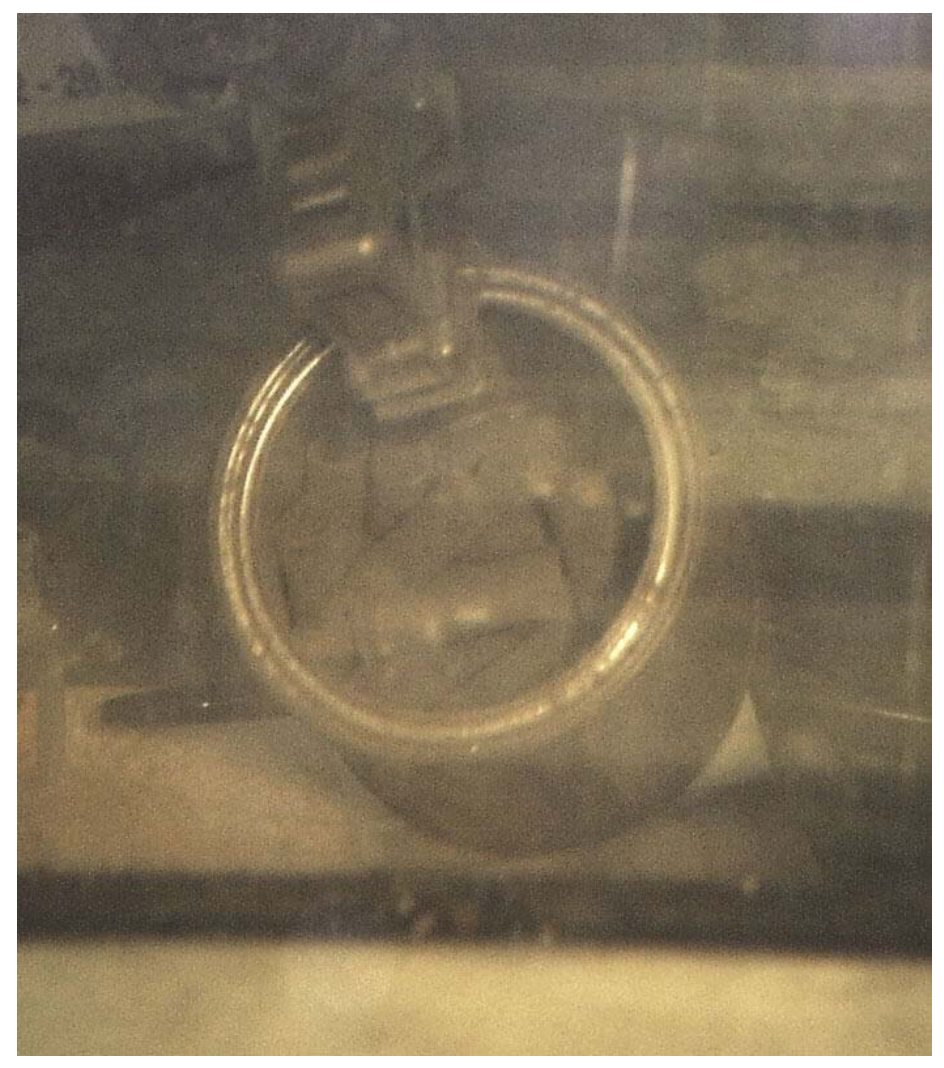

\section{Figure 1. Photograph (taken through remote cell window) of as-received Dresden reactor fuel in can.}

into a 20 L polyethylene carboy. In general, each batch required 14 hours of dissolution time spread over two to three days. Before the cladding was removed from the dissolver, $\sim 1 \mathrm{~L}$ of $4 \mathrm{M} \mathrm{HNO}_{3}$ (that was used for starting the next dissolution) was added to the dissolver, and the solution was heated to $\sim 90^{\circ} \mathrm{C}$ for $2-6$ hours. The leached cladding was then removed from the dissolver and the next batch of fuel was charged to the partially spent acid heel.

At the end of the third dissolution, it was not possible to decant the dissolver product and add a fresh $1 \mathrm{~L}$ aliquot of $4 \underline{\mathrm{M}} \mathrm{HNO}_{3}$ because of the desire to keep the $\left[\mathrm{H}^{+}\right]$near $1.5 \mathrm{M}$. Instead, the cladding was soaked in the dissolver product, at $\sim 90^{\circ} \mathrm{C}$, for about 7 hours in an attempt to digest any $\mathrm{UO}_{2}$ that remained. The dissolver product solution was allowed to cool overnight, which resulted in the precipitation of a considerable volume of needlelike and plate-like particles with shiny, faceted surfaces. The precipitated material, which was believed to be $\mathrm{UO}_{2}\left(\mathrm{NO}_{3}\right)_{2}$, was redissolved by adding $\sim 2.4 \mathrm{~L}$ deionized/demineralized water and heating to $\sim 90^{\circ} \mathrm{C}$. Figure 2 shows a random sampling of the cladding after dissolution of the fuel meat. In total, $875 \mathrm{~g}$ of cladding were 
recovered from the dissolution experiments. It is from this material that the samples studied in the present work were selected.

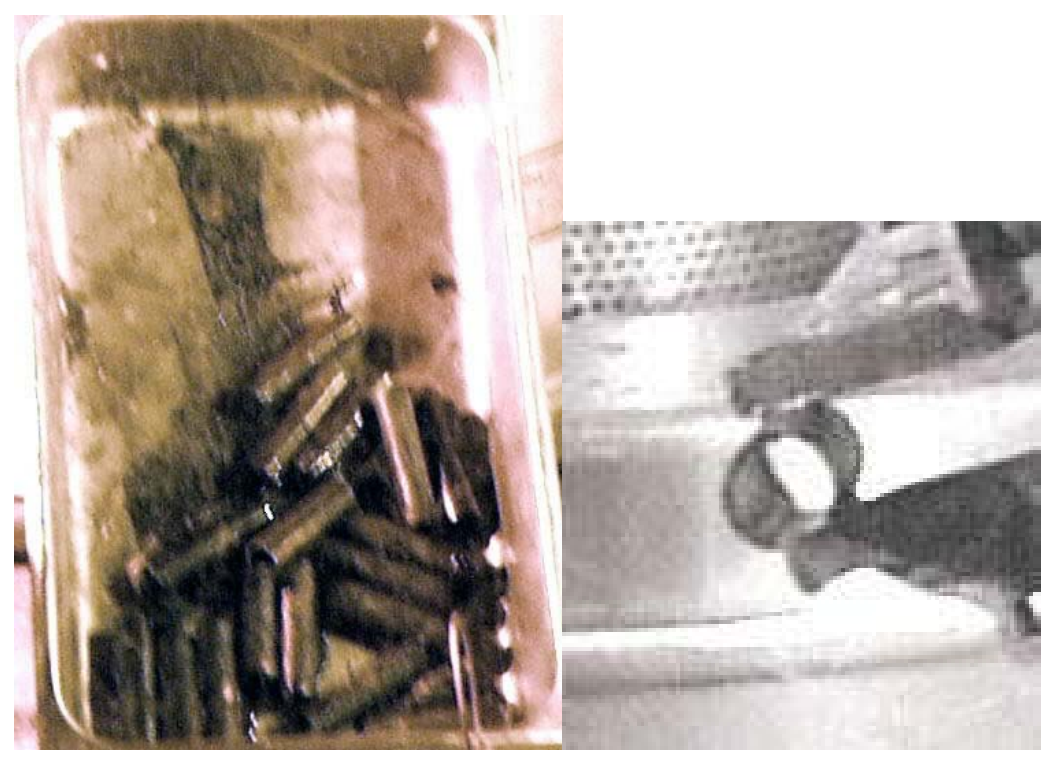

Figure 2. Photographs of cladding (after fuel meat dissolution) taken through cell window.

\section{Sample Preparation}

Because of the high radiation fields associated with the cladding, samples of cladding were remotely sectioned from randomly selected cladding pieces using a manipulatorheld manual tubing cutter. The sectioned rings of material were crushed in a steel vise and smaller pieces 'broken off” the larger piece using a steel hammer. The resulting pieces of material were washed three times with deionized/demineralized water. The resulting samples, with masses in the range $0.25-0.45 \mathrm{~g}$, were removed from the remote environment and processed in a radiochemical laboratory fume hood. Each sample was dissolved in concentrated HF ( 29.5 M HF). A dissolution blank was also prepared during the dissolution activity. The resulting solutions (and blank) were each diluted to $100.00 \mathrm{~mL}$ with deionized/demineralized water and homogenized.

One ring of cladding material was not crushed and broken into pieces. Instead, it was washed three times in deionized/demineralized water, removed from the remote environment for analysis in its "as received" condition.

\section{Results}

The cladding samples were analyzed by a variety of standard instrumental techniques that included inductively-coupled plasma mass spectrometry (ICP-MS), inductively-coupled plasma emission spectroscopy (ICP-ES), scanning electron microscopy-energy dispersive spectroscopy (SEM-EDS), and a suite of radiochemical techniques - gamma scan $(\gamma-$ scan), Plutonium Isotopic Determination and Technetium-99 determination. The results of these analyses, and the reasons the techniques were employed, are presented below. 


\section{ORIGEN2 Calculations}

At the completion of the experimental work associated with fuel dissolution, a report was written. ${ }^{6}$ Discussion with personnel at ANL-Chicago ${ }^{7}$ revealed that during work at ANLChicago with similar Zircaloy-clad spent fuels, some of the same issues related to analysis of insoluble residues and cladding were encountered. During the studies at ANL-Chicago, the ORIGEN $2^{8}$ code was used to predict the characteristics of the fuel studied. This code can be used to predict a variety of characteristics of nuclear materials, such as nuclide masses, fractional isotopic compositions of elements, radioactivity, and thermal power. Personnel at ANL-Chicago transmitted the output from their ORIGEN2 calculations performed on a $\mathrm{UO}_{2}$ fuel similar to the Dresden fuel studied in the present work. The model calculations were performed for a burn-up of 39,941 MWday/t, with out-of-reactor cooling times up to 21 years. While these burn-ups and cooling times are not equivalent to those associated with the Dresden-1 fuel studied during the present work (actual burn-up of 23,480 MWday/t and about 27 years out-of-reactor cooling time), the calculations provide a theoretically-based, rough estimate of the fission product and actinide contents in the Dresden-1 fuel. The ORIGEN2 output predictions for some of the fission products and $\mathrm{Pu}$, are presented in Table 1. Based on SRTC special nuclear material accountability records, the Dresden-1 fuel was expected to contain $28.54 \mathrm{~g}$ of $^{239-}$

${ }^{241} \mathrm{Pu}$, which is slightly lower than the ORIGEN2 calculated value $36.92 \mathrm{~g}$.

Table 1. ORIGEN2-generated Predictions for Fission Product and Actinide Content in Irradiated, Zircaloy-Clad $\mathrm{UO}_{2}$ Fuel $^{*}$

\begin{tabular}{|c|c|c|}
\hline Element & Mass $/\left(g_{\text {element }} / t_{\text {heavy metal }}\right)$ & Mass in $4.54 \mathrm{~kg} \mathrm{UO}{ }_{2}^{\#} /(\mathrm{g})$ \\
\hline $\mathrm{Ag}$ & 78.53 & 0.3141 \\
\hline $\mathrm{Ce}$ & 2847. & 11.39 \\
\hline $\mathrm{Gd}$ & 144.6 & 0.5784 \\
\hline $\mathrm{La}$ & 1476. & 5.904 \\
\hline $\mathrm{Sb}$ & 22.07 & 0.08828 \\
\hline $\mathrm{Sn}$ & 107.1 & 0.4284 \\
\hline $\mathrm{Pu}_{\text {total }}$ & 9385. & 37.54 \\
\hline${ }^{239-241} \mathrm{Pu}$ & 9231. & 36.92 \\
\hline \multicolumn{3}{|c|}{ 39,941 MWday/t burn-up, 21 years out of reactor cooling. } \\
\hline
\end{tabular}

\section{ICP-ES}

The ICP-ES analyses were performed to determine the chemical composition of the cladding. Aliquots of the blank and the two sample solutions were analyzed after dilution by a factor of 2.00. Each sample (including the blank) was analyzed three times, and the three spectra were averaged. The results presented in Table 2 are the average of the "difference spectra" (sample signal - blank signal, for each spectral line result) computed for the two cladding samples. 
Table 2. ICP-ES Results for Dresden-1 SNF Zircaloy 2 Cladding

\begin{tabular}{|c|c|}
\hline Analyte & $\mathbf{m g}_{\text {analyte }} / \mathbf{g}_{\text {sample }}$ \\
\hline $\mathrm{Ag}$ & 4.344 \\
\hline $\mathrm{B}$ & 15.44 \\
\hline $\mathrm{Ba}$ & 0.05353 \\
\hline $\mathrm{Cd}$ & 0.01462 \\
\hline $\mathrm{Ce}$ & 5.348 \\
\hline $\mathrm{Cr}$ & 0.9837 \\
\hline $\mathrm{Cu}$ & 0.058419 \\
\hline $\mathrm{Fe}$ & 1.7553 \\
\hline $\mathrm{Gd}$ & 0.2014 \\
\hline $\mathrm{La}$ & 0.1220 \\
\hline $\mathrm{Mn}$ & 0.04210 \\
\hline $\mathrm{Mo}$ & 0.9242 \\
\hline $\mathrm{Na}$ & 3.2622 \\
\hline $\mathrm{Ni}$ & 0.3025 \\
\hline $\mathrm{P}$ & 0.8089 \\
\hline $\mathrm{S}$ & 0.1026 \\
\hline $\mathrm{Sb}$ & 0.3444 \\
\hline $\mathrm{Sn}$ & 22.30 \\
\hline $\mathrm{Sr}$ & 0.5556 \\
\hline $\mathrm{Ti}$ & 0.01997 \\
\hline $\mathrm{U}$ & 0.9080 \\
\hline $\mathrm{V}$ & 0.01346 \\
\hline $\mathrm{Zr}$ & 956.9 \\
\hline
\end{tabular}

Because essentially all the $\mathrm{Zr}, \mathrm{Sn}, \mathrm{Fe}$, and $\mathrm{Cr}$ present in the cladding was present before irradiation, the relative amounts of these elements can be used to assess the reliability of the ICP-ES data. A typical composition of Zircaloy-2 is shown in Table 3. From the data in Table 3, the ranges of the ratios Zr:Sn, Zr:Fe, Zr:Cr, Sn:Fe, Sn:Cr, and Fe:Cr that would be expected to be present in Zircaloy-2, were computed and tabulated in Table 4. These values were then compared to the values in Table 5, which were computed from the ICP-ES results in Table 2. Other than the Zr:Sn ratio, the ICP-ES generated ratios (Table 5) are in excellent agreement with the ratios computed from the expected composition of Zircaloy-2. Possible reasons for the deviation of the ICP-ES Zr:Sn ratio from the expected value will be explored later in the Discussion section.

Perusal of the results presented in Table 2 reveals that only a few elements are present in greater than parts-per-million ( $\mathrm{ppm}$ ) concentrations. Of those, the analyte elements, $\mathrm{Ag}$, $\mathrm{B}, \mathrm{Ce}, \mathrm{Gd}, \mathrm{La}$, and $\mathrm{Na}$ are of particular interest because of their large concentrations. Inspection of the blank results (which are not presented in this result for the sake of brevity), showed that the B result was computed from the difference of two large values (B was present in the blank and analyzed solutions at over $5 \mathrm{~g} / \mathrm{L}$ ). For this reason, it is concluded that B is probably present as an artifact due to the interaction of the HF sample 
media and the glass inlet system of the ICP-ES instrument. In addition, $\mathrm{Na}$ appears to be present as a contaminant. Discussion supporting these interpretations will be presented later in the Discussion.

Table 3. Zircaloy-2 Composition

\begin{tabular}{|c|c|}
\hline Element & Composition / weight \% \\
\hline $\mathrm{Sn}$ & $1.3-1.6$ \\
\hline $\mathrm{Fe}$ & $0.07-0.20$ \\
\hline $\mathrm{Cr}$ & $0.05-0.16$ \\
\hline $\mathrm{Ni}$ & $0.03-0.08$ \\
\hline $\mathrm{N}$ & $0.23-0.32$ \\
\hline Average (Fe + Cr + Ni) & 0.006 \\
\hline Total Impurities (other elements) & $<0.1281$ \\
\hline Zr (by difference) & $97.9-98.3$ \\
\hline all values except Zr from G. L. Miller, Zirconium, Academic Press, Inc., New York, p.240 (1957) \\
\hline
\end{tabular}

Table 4. Expected Elemental Ratios for Zircaloy-2

\begin{tabular}{|c|c|}
\hline & Table 4 \\
\hline Element $_{\mathbf{1}} \mathbf{E l e m e n t}_{\mathbf{2}}$ & Mass $_{\mathbf{1}}$ / $_{\mathbf{M a s s}} \mathbf{2}$ \\
\hline $\mathrm{Zr}: \mathrm{Sn}$ & $61.2-75.6$ \\
\hline $\mathrm{Zr}: \mathrm{Fe}$ & $490-1405$ \\
\hline $\mathrm{Zr}: \mathrm{Cr}$ & $612-1966$ \\
\hline $\mathrm{Sn}: \mathrm{Fe}$ & $6.5-22.9$ \\
\hline $\mathrm{Sn}: \mathrm{Cr}$ & $8.1-32$ \\
\hline $\mathrm{Fe}: \mathrm{Cr}$ & $0.44-4$ \\
\hline${ }^{*}$ calculated using values from Table 3 \\
\hline
\end{tabular}

Table 5. Computed Elemental Ratios for Dresden-1 Zircaloy-2 Cladding*

\begin{tabular}{|c|c|}
\hline Element $_{\mathbf{1}}:$ Element $_{\mathbf{2}}$ & Mass $_{\mathbf{1}} / \mathbf{M a s s}_{\mathbf{2}}$ \\
\hline $\mathrm{Zr}: \mathrm{Sn}$ & 42.9 \\
\hline $\mathrm{Zr}: \mathrm{Fe}$ & 545 \\
\hline $\mathrm{Zr}: \mathrm{Cr}$ & 973 \\
\hline $\mathrm{Sn}: \mathrm{Fe}$ & 12.7 \\
\hline $\mathrm{Sn}: \mathrm{Cr}$ & 22.7 \\
\hline $\mathrm{Fe}: \mathrm{Cr}$ & 1.78 \\
\hline${ }^{*}$ computed with values from Table 3 & \\
\hline
\end{tabular}

In an attempt to understand the concentrations of the other elements (especially Ag), discussion were held with personnel from ANL-Chicago who had performed ORIGEN2 calculations on irradiated reactor fuels similar to Dresden-1 fuel (burn-up 39,941 MWday/t U, cooled 21 years). Based on the ANL-Chicago results, the maximum quantities of $\mathrm{Ag}, \mathrm{Ce}, \mathrm{Gd}, \mathrm{La}$, and $\mathrm{Sb}$ expected to be present in the Dresden-1 fuel were predicted; these results are presented in Table 6 , along with the actual amounts believed 
to be present (assuming that the samples analyzed were representative of the entire $875 \mathrm{~g}$ of Dresden-1 cladding recovered after the dissolution experiments). ${ }^{\text {ii }}$

Table 6. Actual and Predicted Maximum Analyte Abundances in Dresden-1 Cladding

\begin{tabular}{|c|c|c|}
\hline Analyte & ICP-ES / $\mathbf{~ m g a n a l y t e ~} / \mathbf{g}_{\text {sample }}$ ) & ORIGEN2 / $\left(\mathbf{m g}_{\text {analyte }} / \mathbf{g}_{\text {sample }}\right)^{*}$ \\
\hline $\mathrm{Ag}$ & 4.344 & 0.3878 \\
\hline $\mathrm{Ce}$ & 5.348 & 14.0593 \\
\hline $\mathrm{Gd}$ & 0.2014 & 0.6610 \\
\hline $\mathrm{La}$ & 0.1220 & 7.2889 \\
\hline $\mathrm{Sb}$ & 0.3444 & 0.1090 \\
\hline $\mathrm{Sn}$ & 22.30 & 0.5289 \\
\hline \multicolumn{2}{|c|}{$\begin{array}{l}\text { These "Maximum Analyte Abundances" were computed based on the assumption that the entire fission product } \\
\text { inventory from the dissolved fuel resides in the cladding. }\end{array}$} \\
\hline
\end{tabular}

These results suggest that the Ag and Sb values from the ICP-ES results are too high; it is not possible to evaluate the reliability of the results for $\mathrm{Ce}, \mathrm{Gd}$, and La based only on the ORIGEN2 results. A discussion of the reliability of the ICP-ES results will be presented later in the Discussion section.

\section{ICP-MS}

ICP-MS analyses were performed on the sample solutions and blank to aid in the determination of the chemical composition of the cladding. Two types of scans were performed. The first was a fission product scan, which enveloped the $\mathrm{m} / \mathrm{z}$ range 80 to 195. The second was an actinide scan, which includes the portion of the mass spectrum with $\mathrm{m} / \mathrm{z}$ values $\geq 230$. These scans are shown in Figures 3,4 , and 5 , with an additional high sensitivity plot of the actinide spectrum shown in Figure 6.

The fission product spectrum is quite complex. There is signal at essentially every integral $\mathrm{m} / \mathrm{z}$ value across the spectrum (Figures 3 and 4), especially in the range 115 to 160 , and most every integral $\mathrm{m} / \mathrm{z}$ has associated with it more than a single isotope, rendering the spectrum of little assistance when attempting to determine the chemical composition of the cladding. The fission product spectrum is further complicated by the calibration of the instrument. Because of the broad range of signals, a few thousand counts up to $10^{6}$ counts, it was not possible to calibrate the instrument over the entire range of signals. Instead, the calibration of the instrument was performed at the lower end of the range of signals. While this calibration renders the signal that is attributable to $\mathrm{Zr}, \mathrm{m} / \mathrm{z}=90$ to 96 , useless when interpreting the results of these measurements, it does not impact other elements such as $\mathrm{Sn}$. For this reason, the fission product spectrum has been used primarily as an "internal standard" for the actinide results as described below.

Because of the large mass of Sn (it is present in the cladding at more than $1 \%$ by mass), the fission product contribution to the signal, at the more abundant $\mathrm{Sn}$ isotopes, $\mathrm{m} / \mathrm{z}=$

\footnotetext{
ii The Table also contains a computed result for total fission product Sn from the ORIGEN2 calculation, as this value is useful when interpreting the reliability of the ICP-ES and ICP-MS results (included later in the Discussion section).
} 
$118-120$, is expected to be essentially inconsequential as compared to the contribution from the cladding (based on the total mass of fission product Sn expected to be present in the fuel - see Table 6. above). Thus, the $\mathrm{m} / \mathrm{z} 120: 119$ and 120:118 ratios should be in good agreement with those ratios for naturally-occurring $\mathrm{Sn}$ if the samples were, in fact, representative in of the bulk of the cladding. Inspection of the results presented in Table 7 shows excellent agreement of the ICP-ES results and those for naturally-occurring $\mathrm{Sn}$

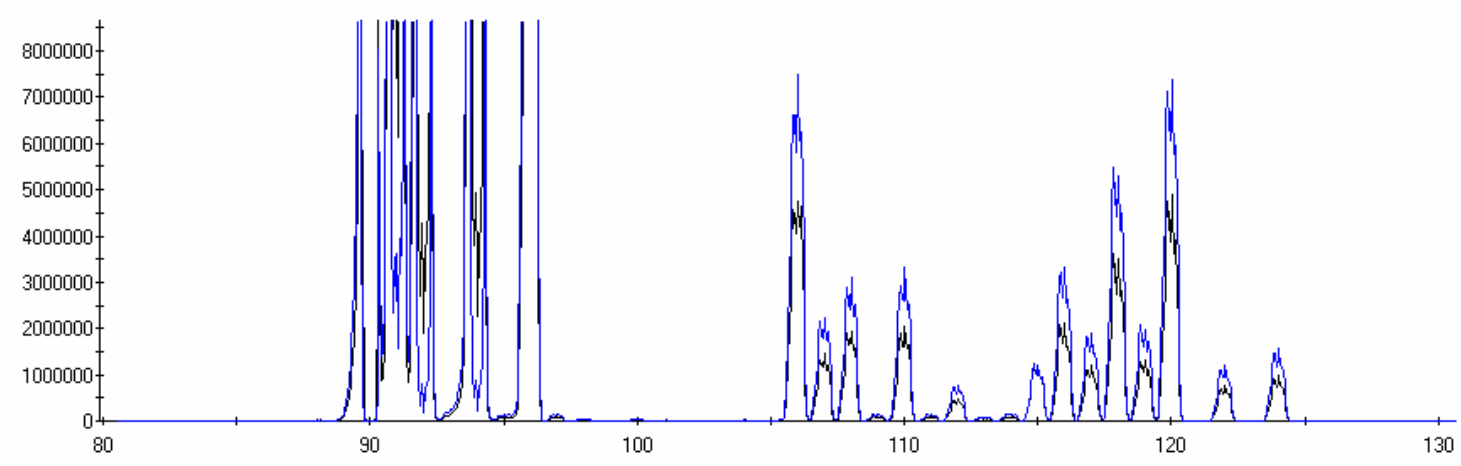

Figure 3. ICP-MS fission product spectrum, $m / z=80$ to 130 .

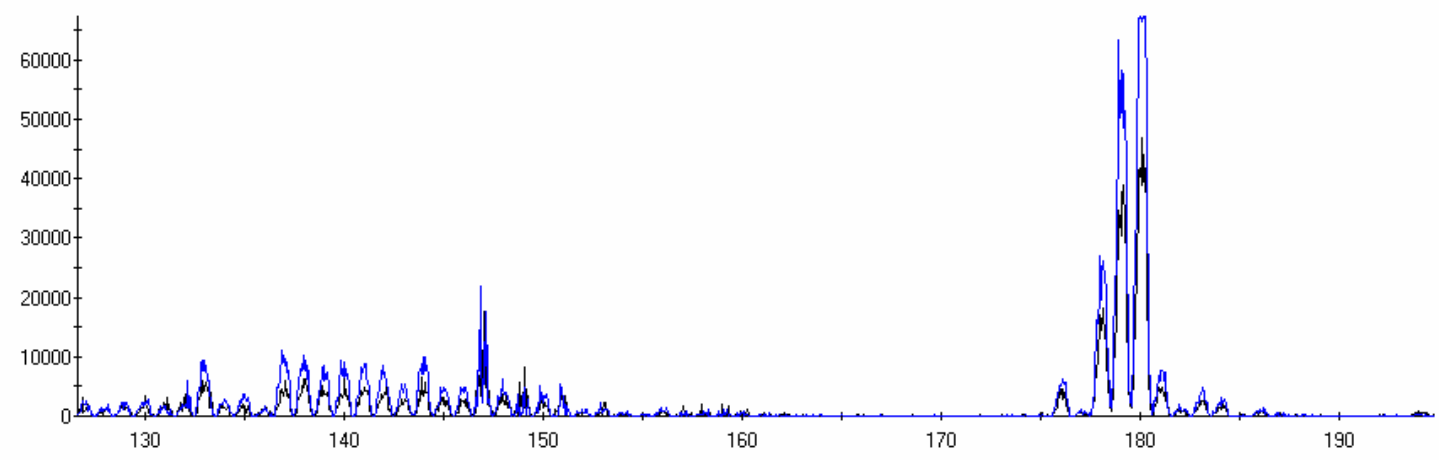

Figure 4. ICP-MS fission product spectrum, m/z=125 to 195 .

Since there many fewer elements with isotopes in the $\mathrm{m} / \mathrm{z}>230$ range, the actinide ICPMS spectra are more easily interpreted. Representative spectra from one of the data collections, displayed in Figures 5 and 6, show that signal above background was clearly present at $\mathrm{m} / \mathrm{z}$ values $235,236,238,239,240,241$, and 242 . The results, in $\mu g_{\text {analyte }} / g_{\text {sample }}$, along with the isotopes believed to correspond to the signals producing the results, are shown in Table 8.

The signal at $\mathrm{m} / \mathrm{z}=237$ was present in the spectra in Figures 5 and 6 , but not others, so it was not included in the data analysis. Discussion and justification of this choice are presented later in the Discussion section. 


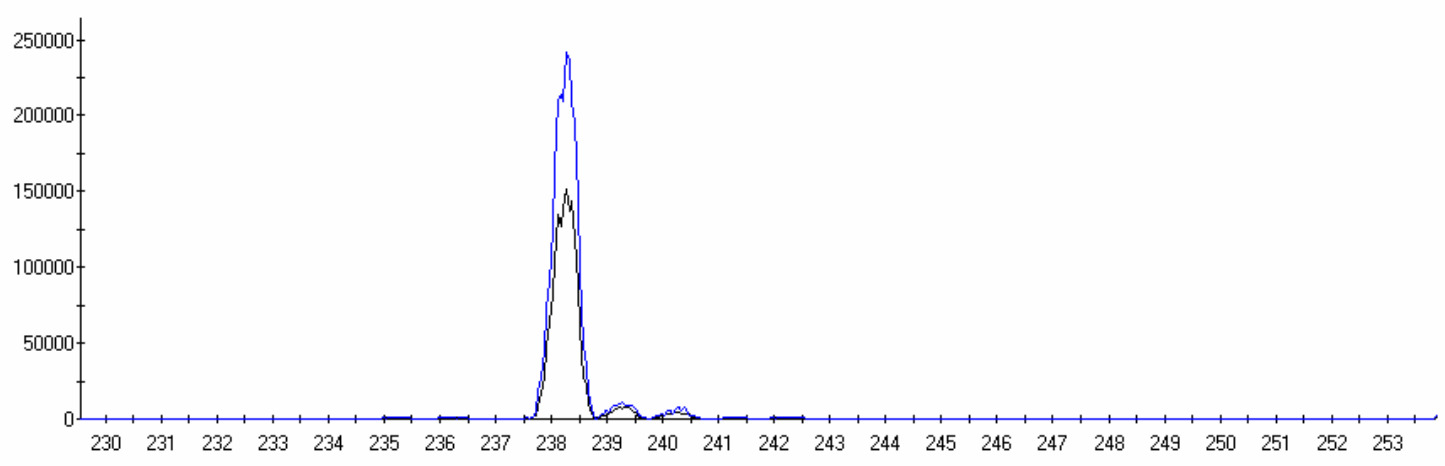

Figure 5. ICP-MS actinide spectrum, $\mathrm{m} / \mathrm{z}=229.5$ to 255 , low sensitivity. The dual traces are due to different dilutions of the sample (the more intense signal is due to a 2X more concentrated sample).

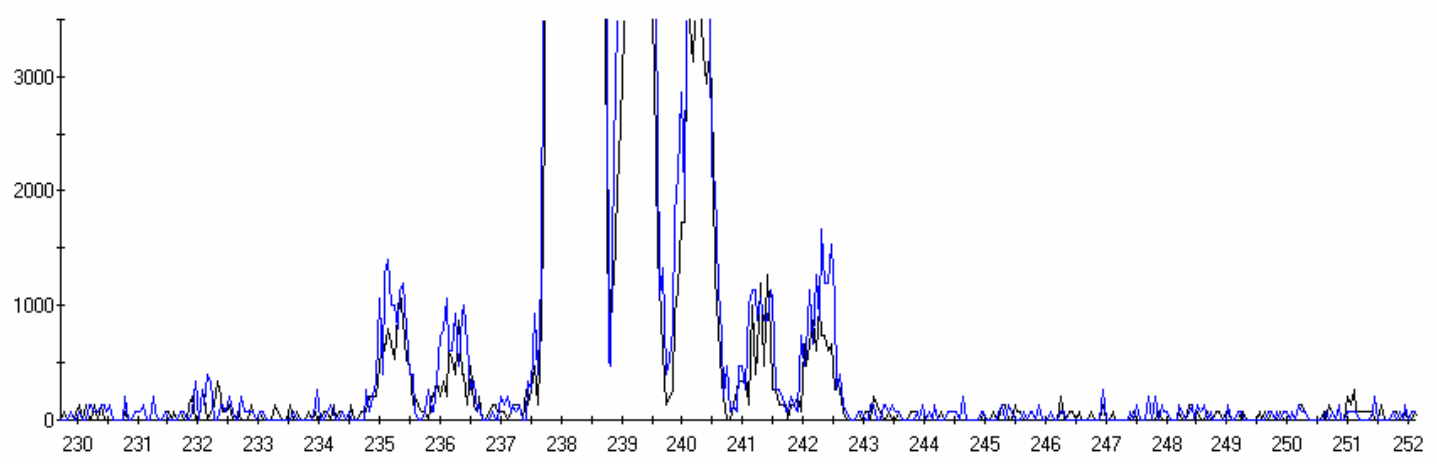

Figure 6. ICP-MS actinide spectrum, $\mathrm{m} / \mathrm{z}=229.5$ to 252 , high sensitivity.

Table 7. Tin Isotope Ratios

\begin{tabular}{|c|c|c|}
\hline Isotope Ratio & ICP-MS Ratio & $\begin{array}{c}\text { Naturally-Occurring } \\
\text { Ratio }\end{array}$ \\
\hline${ }^{120} \mathrm{Sn} /{ }^{119} \mathrm{Sn}$ & 3.97 & 3.84 \\
\hline${ }^{120} \mathrm{Sn} /{ }^{118} \mathrm{Sn}$ & 1.41 & 1.37 \\
\hline
\end{tabular}

Table 8. Averaged ICP-MS Actinide Results for Dresden-1 Zircaloy-2 Cladding

\begin{tabular}{|c|c|c|}
\hline Mass/z & Probable Element & $\boldsymbol{\mu g}$ element/g sample \\
\hline 235 & $\mathrm{U}$ & 0.71 \\
\hline 236 & $\mathrm{U}$ & 0.39 \\
\hline 238 & $\mathrm{U}($ major $), \mathrm{Pu}($ minor $)$ & 142.78 \\
\hline 239 & $\mathrm{Pu}$ & 11.23 \\
\hline 240 & $\mathrm{Pu}$ & 3.85 \\
\hline 241 & $\mathrm{Am}($ major $), \mathrm{Pu}($ minor $)$ & 0.74 \\
\hline 242 & $\mathrm{Pu}$ & 0.76 \\
\hline
\end{tabular}




\section{Radiochemical Analyses}

A suite of radiochemical analyses were performed to determine the isotopic distribution of $\mathrm{Pu}$, and the amounts of $\mathrm{Am}, \mathrm{Tc}$, and other radionuclides present in the cladding. For the sake of clarity and brevity, the results from these analyses will be presented "en mass" in Table 9.

As-received solutions were subjected to a $\gamma$-scan to identify $\gamma$ emitters. Another aliquot of the sample solution was then subjected to anion exchange separation to remove $\mathrm{Pu}$, which is eluted from the separation column and determined by $\gamma$ pulse counting. These analyses provide results for ${ }^{238} \mathrm{Pu},{ }^{241} \mathrm{Pu}$, and ${ }^{239 / 240} \mathrm{Pu}$. The partitioning of the ${ }^{239 / 240} \mathrm{Pu}$ signal can be based on the relative intensities of the $\mathrm{m} / \mathrm{z} 239$ and 240 signals from the ICP-MS results since there are no abundant species at m/z 239 and 240 other than the $\mathrm{Pu}$ isotopes.

The ${ }^{99} \mathrm{Tc}$ analysis also involves a separation. The Tc is separated from a fresh aliquot of the sample solution by anion exchange of the Tc, followed by elution of the Tc from the column. The Tc solution is spiked with the short-lived ${ }^{99 \mathrm{~m}} \mathrm{Tc}$ isotope, and the spiked solution is counted to determine the ${ }^{99} \mathrm{Tc}$ content. The abundance of ${ }^{99} \mathrm{Tc}$ in the dissolved cladding samples was, in all cases, below the detection limit.

The ${ }^{155} \mathrm{Eu}$ and ${ }^{237} \mathrm{~Np}$ abundances in these samples were quite low. There were detectable amounts of these nuclides in one of the samples analyzed; however, none was detected in the other samples analyzed.

Table 9. Radiochemical Results for Dresden-1 Zircaloy-2 Cladding

\begin{tabular}{|c|c|c|}
\hline Analyte & Technique & $\mu g_{\text {analyte }} / g_{\text {sample }}$ \\
\hline${ }^{60} \mathrm{Co}$ & $\mathrm{a}$ & $2.92 \times 10^{-3}$ \\
\hline${ }^{99} \mathrm{Tc}$ & $\mathrm{b}$ & BDL \\
\hline${ }^{125} \mathrm{Sb}$ & $\mathrm{a}$ & $1.10 \times 10^{-3}$ \\
\hline${ }^{137} \mathrm{Cs}$ & $\mathrm{a}$ & $2.65 \times 10^{-3}$ \\
\hline${ }^{154} \mathrm{Eu}$ & $\mathrm{a}$ & $6.88 \times 10^{-3}$ \\
\hline${ }^{155} \mathrm{Eu}$ & $\mathrm{a}$ & inconclusive \\
\hline${ }^{237} \mathrm{~Np}$ & $\mathrm{a}$ & inconclusive \\
\hline${ }^{238} \mathrm{Pu}$ & $\mathrm{c}$ & 0.133 \\
\hline${ }^{239} \mathrm{Pu}$ & $\mathrm{d}$ & 6.34 \\
\hline${ }^{240} \mathrm{Pu}$ & $\mathrm{d}$ & 0.217 \\
\hline${ }^{241} \mathrm{Pu}$ & $\mathrm{c}$ & 0.340 \\
\hline Total $\mathrm{Pu}$ & $\mathrm{c}, \mathrm{d}$ & 8.99 \\
\hline${ }^{241} \mathrm{Am}$ & $\mathrm{a}$ & 0.307 \\
\hline \multicolumn{3}{|c|}{$\begin{array}{l}\text { BDL: below detection limit of method } \\
\text { a: gamma scan } \\
\text { b: }{ }^{99} \text { Tc separation followed by counting } \\
\text { c: Pu separation, } \gamma \text {-pha } \\
\text { d: Pu separation, } \gamma \text {-pha, } 239 / 240 \text { partition based on ICP-MS }\end{array}$} \\
\hline
\end{tabular}




\section{SEM-EDS}

A single sample of cladding was analyzed, in "as received" condition, in a remotely operated SEM (instrument control panels were hands-on, but remainder of instrument is in a glovebox). As described earlier, the piece was a "ring" of cladding material cut from the Zircaloy- 2 residue recovered after the $\mathrm{UO}_{2}$ was leached from the chopped Zircaloy-2 cladding. This analysis was performed in an attempt to determine the location of the actinides contained in the cladding. Figures 7 and 8 show increasingly magnified images of the surface of the cut cladding as well as the locations on the surface that were analyzed.

The surface texture of the as-received sample (Figure 7) shows that the cutter used to cut the samples actually fractured the surface (as opposed to cutting it). The portion of the sample near the outer diameter of the cladding appears to have been cut (note the smoothness and surface striations), while most of the interior of the sample surface is rough. (The bright ring around the lower right-hand side of the cladding picture is a reflection from the side of the sample). Upon higher magnification of the surface, three spots were analyzed. One spot (Spot 1 on Figure 8.) appeared to be representative of the bulk of the surface, while two other spots (Spot 2 on Figure 8.) identified from the backscattered electron image appeared to be different than the rest of the surface. Analysis of Spot 1 identified it as Zr-rich (Figure 9.). Analysis of the Spot 2 locations identified them as nearly pure uranium (Figure 10). Other such spots were also identified at other locations on the surface of the sample and they too were identified as nearly pure U. Both the backscattered and emission images suggested that the U-bearing spots were particles on the surface of the sample. It should be noted that the signals near 7.5 and 8 $\mathrm{keV}$ in the spectra shown in Figures 9,10, and 12 are believed to be a commonlyencountered artifact that is caused by the radiation field associated with highlycontaminated samples.

Elemental analyses were also performed on two other regions of the surface that appeared to be unique (Spot 3 and Spot 4 in Figure 11.). Analysis of Spot 3 (Figure 12.) identified that area as being high in Fe, while analysis of Spot 4 identified that spot as being high in both $\mathrm{Fe}$ and $\mathrm{Zr}$.

\section{Discussion}

Taken individually, the analytical results presented in the Results section appear to be inconsistent. The total $\mathrm{Pu}$ values resulting from the ICP-MS and radiochemical analyses, 15.82 and $8.99 \mu \mathrm{g}_{\text {analyte }} / \mathrm{g}_{\text {sample }}$, appear to be quite divergent. The U content from ICP-MS

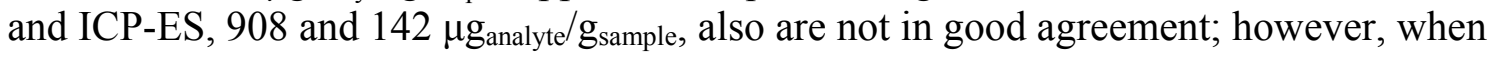
the results are interpreted in the context of the knowledge possessed about the fuel dissolution experiments and the analytical techniques, the results present a compelling story about the efficacy of the $\mathrm{HNO}_{3}$ chop/leach dissolution technique. To facilitate the discussion, this section will be partitioned into two segments: Consistency of Results and Interpretation of Results. 


\section{Consistency of Results}

The consistency of results shall be evaluated in two fashions: internal consistency of the results from each technique and consistency of results between techniques. Internally, the consistency is most easily evaluated if some set of analytes are present in known ratios. Fortunately, the chemical composition of the Zircaloy-2 cladding and the isotopic make-up of its major components, $\mathrm{Zr}$, Sn, $\mathrm{Cr}$, and Fe, are well known, so these values and ratios of these values can serve as an internal standard for the non-radiochemical analytical techniques.

\section{ORIGEN2 Calculations}

The results from the ORIGEN2 calculation can be used to check the reasonability of the results from the chemical analyses. While the ORIGEN2 results may over predict the quantities of $\mathrm{Pu}$ and the fission products of interest (because of the higher assumed burnup), the quantities may be used as upper limits for the amounts of some of the species of interest.

\section{ICP-ES Results}

Because of the presence of the cladding material in such copious quantities, the internal consistency of the ICP-ES technique can be checked in a straight-forward fashion. The ratios of the primary components of the cladding, $\mathrm{Zr}$, Sn, Fe, and $\mathrm{Cr}$, should be present in ratios that are in good agreement with the known compositional ranges of Zircaloy-2. The results of Table 4, Expected Elemental Ratios for Zircaloy-2, and Table 5, Computed Elemental Ratios for Dresden-1 Zircaloy-2 Cladding, are in excellent agreement in all values except the $\mathrm{Zr}$ :Sn ratio. It is not possible to account for this discrepancy even by making the incredible assumption that all the fission product $\mathrm{Sn}$ resides in the cladding. Based on ORIGEN2 calculation on a fuel similar to the Dresden-1 fuel, it is expected that the total amount of fission product accounts for no more than $2.5 \%$ of the mass of the Sn. It is also not reasonable to suspect that considerable $\mathrm{Zr}$ was transmuted to another element. Due to the lack of any other credible explanation, it is suspected that the composition of the Zircaloy-2 cladding may well have been at the lower limit of $\mathrm{Zr}$ content, while the Sn was at its highest limit. These compositional extremes, taken together with a 5\% uncertainty of the measurement of the $\mathrm{Zr}$ and Sn concentrations, can account for the discrepancy. Increasing the Sn concentration by 5\% and decreasing the $\mathrm{Zr}$ concentration by $5 \%$, as compared to their respective high and low compositional limits, reduces the computed $\mathrm{Zr}$ :Sn ratio to 38.9, which envelopes the value (42.9) computed from the ICP-ES measurements. Based on these considerations, it is possible that the ICP-ES results are a reasonable representation of the of the chemical composition of the cladding with respect to the cladding components.

The abundances of seven other analytes (Ag, B, Ce, Gd, La, Na, and Sb) in the ICP-ES results seemed to stand out because of the quantities of these analytes. The presence of $B$ is easily explainable. Both $\mathrm{Si}$ and $\mathrm{B}$ are present in both the sample and blank spectra. This presence is believed to be due to leaching of the glass inlet system on the ICP-ES. The Si signals in the sample and blank spectra were identical and not particularly large (2.86 mg Si/L sample solution); however, the B signals were quite large (about $5.5 \mathrm{~g} \mathrm{~B} / \mathrm{L}$ sample). The difference between the sample and blank signals for B was less than $1 \%$ of 
the overall signal, calling into question the presence of B at levels above those present in the blank.

The high $\mathrm{Na}$ is suspected to be a result of contamination from the sample storage and cutting operations in the high activity cells. $\mathrm{Na}$ is a common contaminant in the environment, and it is difficult to keep objects in the cells in pristine condition, so the presence of $\mathrm{Na}$ is neither surprising nor troubling, as it doesn't appear to impact the other analytical results.

Based on the predicted results from the ANL-Chicago ORIGEN2 calculations, the amounts of $\mathrm{Ag}$ and $\mathrm{Sb}$ are clearly too high. The results presented in Table 6 show the amount of Ag expected to be present in the Dresden-1 cladding if all of the Ag from the approximately $4.5 \mathrm{~kg}$ of $\mathrm{UO}_{2}$ initially present in the dissolved fuel meat were to reside in the cladding. The ICP-ES results for Ag are about 11 times larger than this total amount of Ag. Since it is clear that this value is too high, it is possible that a more reasonable estimate for the Ag content might be based on the U content (implicit in this approach is the assumption that the solubilities of these metals in Zircaloy are roughly equivalent due to the complexity of the chemical system this may or may not be a reasonable assumption). The $\mathrm{U}$ content in the cladding is $0.908 \mathrm{mg} / \mathrm{g}_{\text {cladding. }}$.

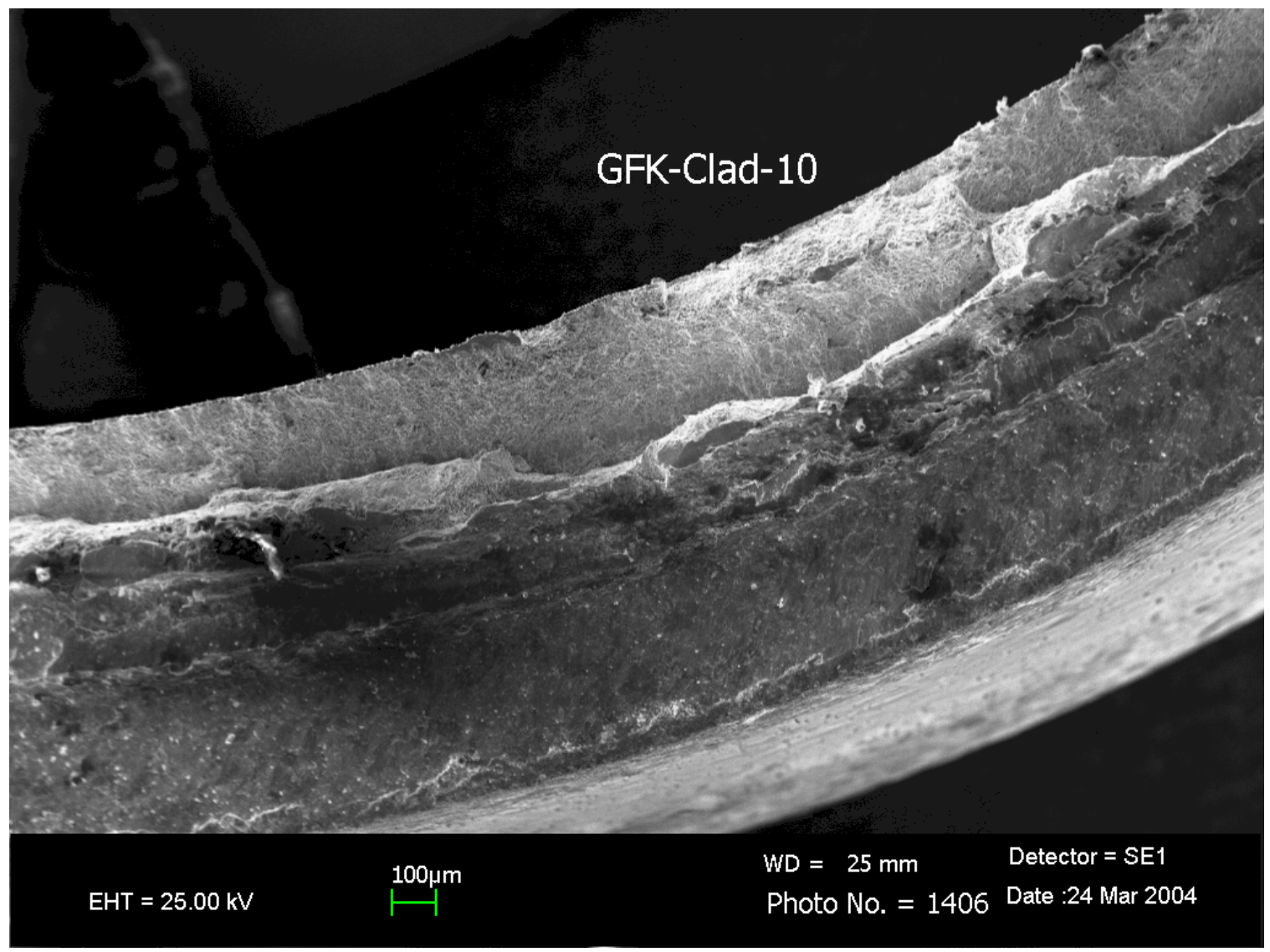

Figure 7. Emitted electron image of as-received cladding slice, 40x magnification. 


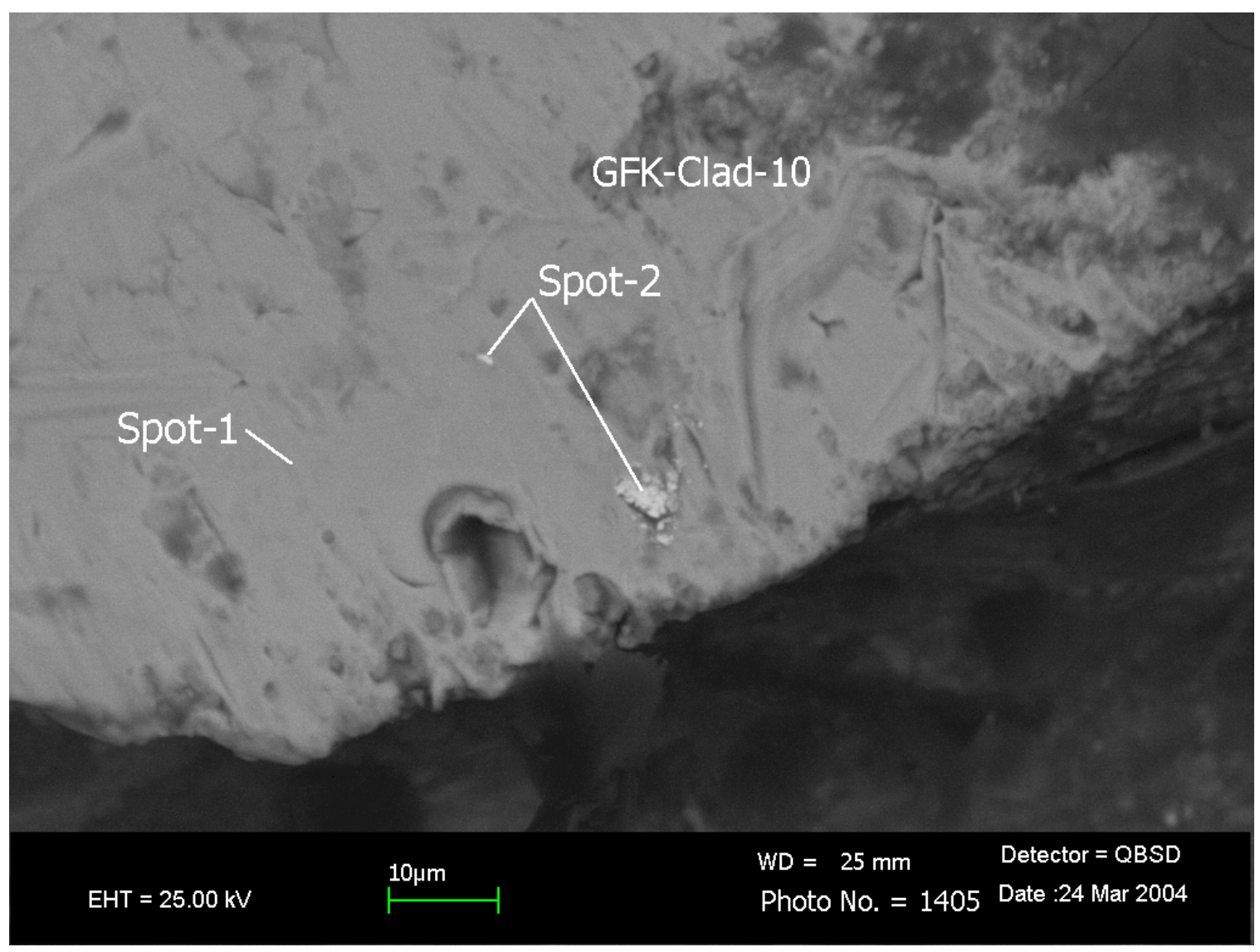

Figure 8. Back scattered electron image of the surface of the as-received slice of cladding, 1000x magnification.

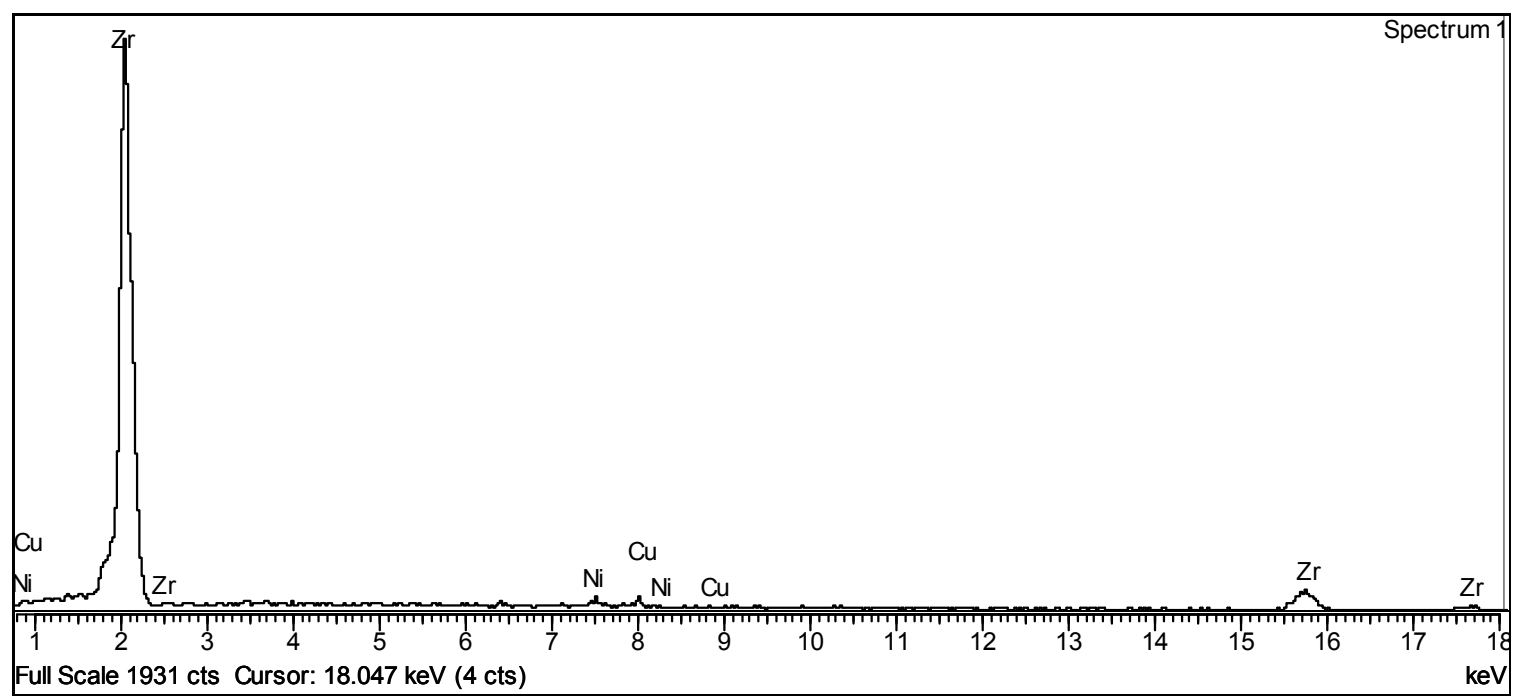

Figure 9. SEM-EDS spectrum of Spot 1. 


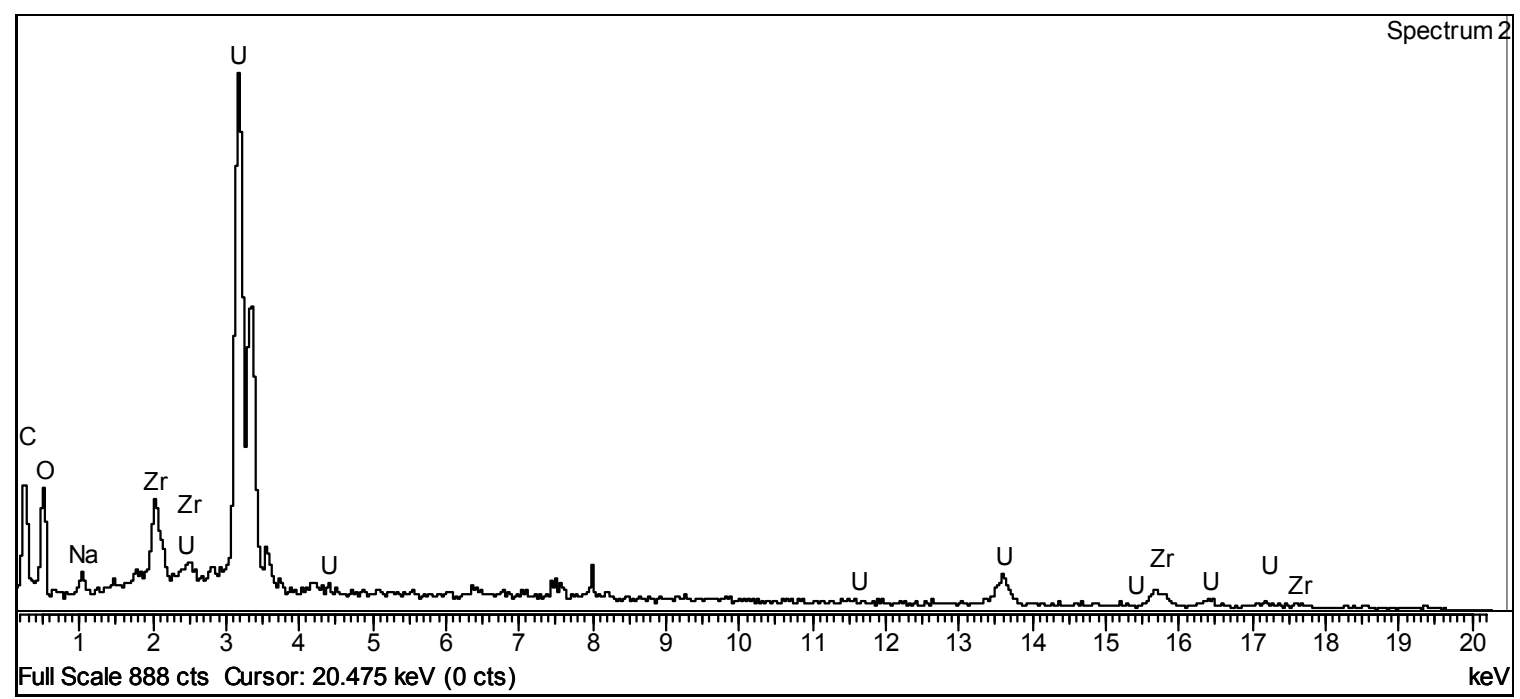

Figure 10. The EDS spectrum of Spot 2.

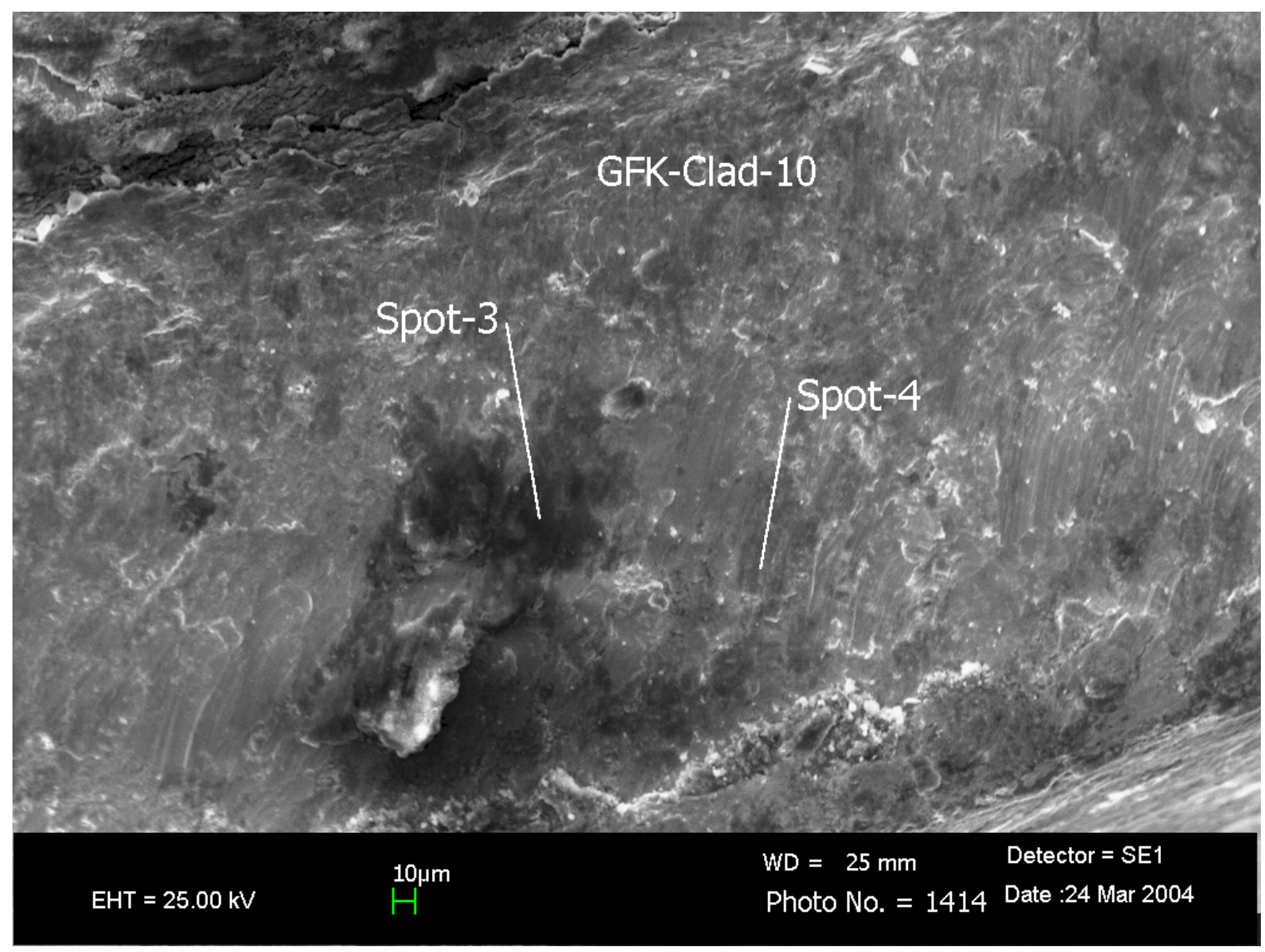

Figure 11. Electron emission image of surface of as-received sample at Spots 3 and $4,200 x$ magnification. The bright spots in this image indicate the topography (high spots) on the sample surface. 


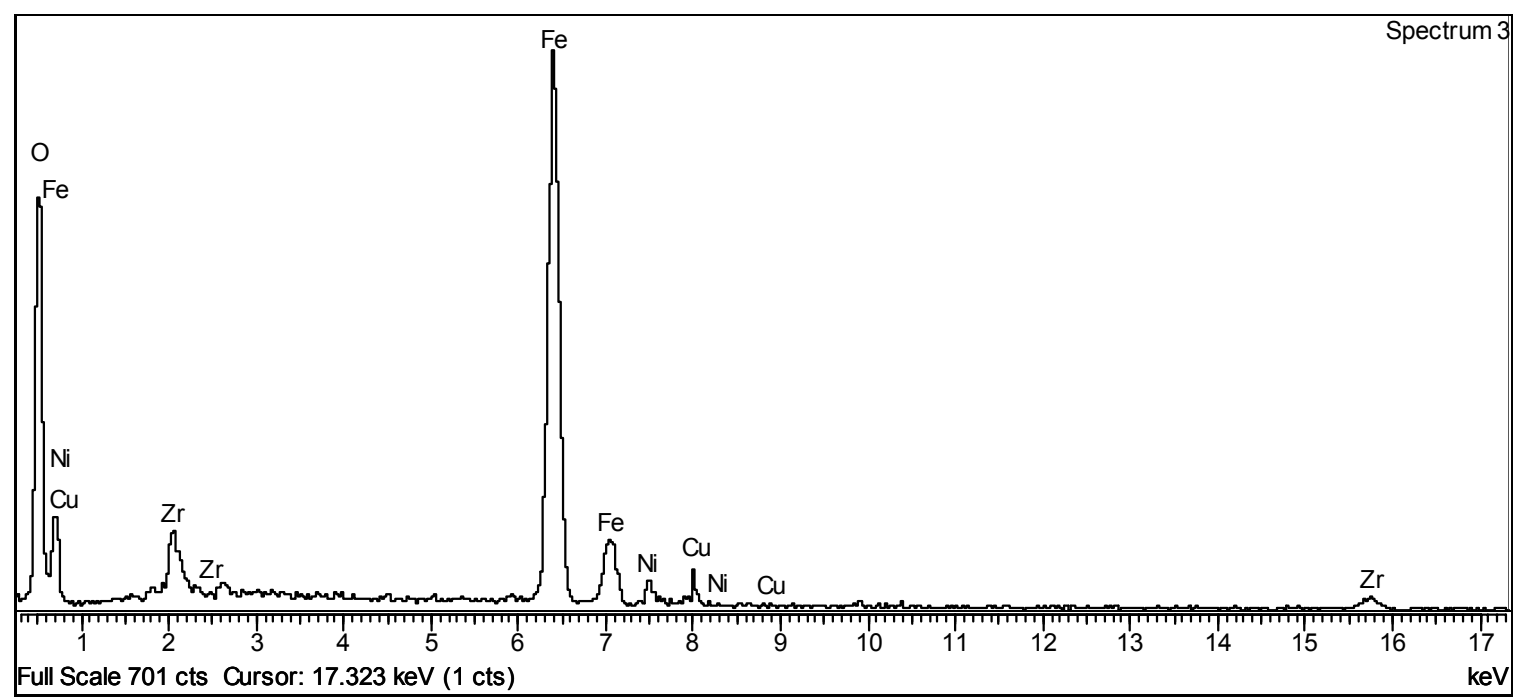

Figure 12. SEM-EDS spectrum of Spot 3.

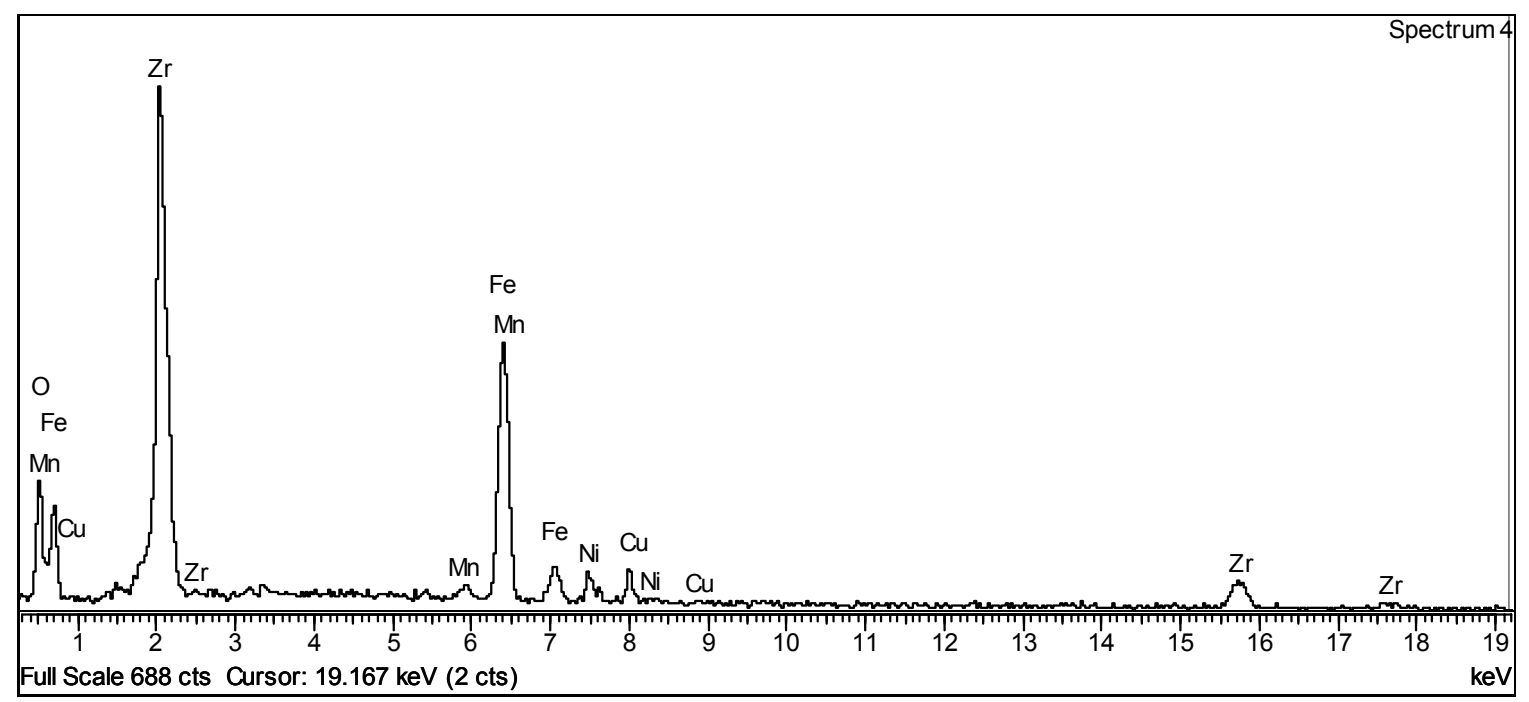

Figure 13. SEM-EDS spectrum of Spot 4.

This quantity corresponds to a total of $0.794 \mathrm{~g} \mathrm{U}$, which is $\sim 0.02 \%$ of the total $\mathrm{U}$ in the fuel before dissolution. Based on the fraction of total $U$ in the cladding, it would be expected that the cladding would contain less than $0.1 \mu \mathrm{g} \mathrm{Ag} / \mathrm{g}_{\text {cladding. }}$

Based on the same arguments as those above, it was concluded that the Sb concentration was also too high, however, the measured value is only 3.2 times greater than the total $\mathrm{Sb}$ content predicted by the ORIGEN2 calculation. Applying the same argument for the partitioning of $\mathrm{Sb}$ to the cladding as was presented for Ag above, it would be expected that $\mathrm{Sb}$ ought to be present at a concentration nearer to $0.022 \mu \mathrm{g} \mathrm{Sb} / \mathrm{g}_{\text {cladding }}$ than the measured value of $0.3444 \mathrm{mg} / \mathrm{g}_{\text {cladding. }}$. 
The situations involving $\mathrm{Ce}, \mathrm{Gd}$, and $\mathrm{La}$ are different than those of $\mathrm{Ag}$ and $\mathrm{Sb}$. Based on the partitioning of $\mathrm{U}$ to the cladding, one would expect the concentrations of $\mathrm{Ce}, \mathrm{Gd}$, and La to be about $2.8,0.13$, and $1.5 \mu \mathrm{g} / \mathrm{g}_{\text {cladding, }}$, respectively; however, these values are many orders of magnitude lower than the measured values.

Based on these arguments, it appears that the ICP-ES results for $\mathrm{Ag}, \mathrm{Sb}, \mathrm{Ce}, \mathrm{Gd}$, and $\mathrm{La}$ are biased high. The problem(s) with these results can probably be traced to the complex solution matrix. During the ICP-ES analysis of solutions containing $\mathrm{U}$, it is recognized that $U$ can cause spectral interference for a variety of other elements. The ICP-ES results presented in this report were checked for such interferences, and were corrected were appropriate. Other actinides can also cause interferences; however, it was not possible to check for, or correct for, those possible interferences. In addition to the interferences due to actinides, the presence of the large variety of d-block and lanthanide elements can also cause interferences because many of these elements, such as $\mathrm{Ag}, \mathrm{Pd}$, and $\mathrm{Rh}$, have transitions that emit at nearly the same wavelengths. Because of the complexity of the solution, the limited scope of this study (the actinides, which contribute to the TRU content of the cladding and will ultimately determine its dispositioning fate, are the trace elements of primary concern), no attempt was made to elucidate the causes of the analytical discrepancies that appear to exist for these fission product elements.

\section{ICP-MS Results}

The ICP-MS results are primarily of use in two venues, qualitative detection of the nuclides of interest and interpretation of the radioanalytical results. In an attempt to determine the reasonability of the ICP-MS results, special interest was focused on the $\mathrm{m} / \mathrm{z}$ values 118-120. Since the isotopic composition of naturally-occurring $\mathrm{Sn}$ is well known, ${ }^{9}$ and the contribution to the ICP-MS signals in the $\mathrm{m} / \mathrm{z}=118-120$ range from other than Sn isotopes is minimal (based on the ORIGEN2 predictions that the contribution of all fission product species at $\mathrm{m} / \mathrm{z}=118-120$ present in the fuel dissolved during this work is less than $5 \mathrm{mg}$ while the mass of $\mathrm{Sn}$ in the cladding is about $5.83 \mathrm{~g}$ ), it was concluded that the ${ }^{120} \mathrm{Sn} /{ }^{119} \mathrm{Sn}$ and ${ }^{120} \mathrm{Sn} /{ }^{118} \mathrm{Sn}$ ratios ought to be in good agreement with those for naturally-occurring Sn. The ratios computed form the ICP-MS results, 3.97 for ${ }^{120} \mathrm{Sn} /{ }^{119} \mathrm{Sn}$ and 1.41 for ${ }^{120} \mathrm{Sn} /{ }^{118} \mathrm{Sn}$, are in excellent agreement with the expected values of 3.97 and 1.37, respectively. Based on these results, it is concluded that the ICP-MS results are reliable.

These results may be used, along with the ORIGEN2 results, to understand the Ag situation. The ORIGEN2 results suggest the only isotope of Ag that contributes significantly to $\mathrm{Ag}$ in the fuel is ${ }^{109} \mathrm{Ag}$. Using the partitioning of $\mathrm{U}$ between the fuel and cladding, it was estimated (earlier in the Discussion of the ICP-ES results), that Ag ought to be present in the cladding at about $0.077 \mu \mathrm{g} / \mathrm{g}_{\text {cladding. }}$. Based on the ICP-MS results for $\mathrm{m} / \mathrm{z}=109$ (Ag is the only significant fission product expected at m/z = 109), Ag ought to be present at $0.10 \mu \mathrm{g} / \mathrm{g}_{\text {cladding. The }}$ The two results are in reasonable agreement, suggesting that the assumption regarding the partitioning of elements to the cladding, based on $\mathrm{U}$ partitioning, is probably reasonable. Lastly, the reliability of the ICP-MS results is 
considered important because the results for $\mathrm{m} / \mathrm{z}=239$ and 240 are needed for interpretation of the radioanalytical results for $\mathrm{Pu}$.

\section{Radioanalytical Results}

The analytes determined by the radioanalytical techniques cannot, in general, be determined by other techniques; therefore, these results are essentially stand-alone results. Dissolution blanks were analyzed along with the samples of interest, and the results were corrected for the blank. Of particular interest are the actinide results, as the presence of those elements will dictate the ultimate disposal path for cladding from an actual process.

The ${ }^{99} \mathrm{Tc}$ analyses showed that this species was below the detection limit and that the bulk of the Tc must have been present in the dissolver product and/or the undissolved solids. Based on analyses of the dissolver product solution (from the dissolution experiments that produced the cladding for the present study), ${ }^{6}$ approximately $22 \mathrm{mg}$ of ${ }^{99} \mathrm{Tc}$ were present in the dissolver product solution. Analyses of the effluents from the solvent extraction experiments involving the dissolver product solution suggest that 22 $\mathrm{mg}$ is much lower than the actual ${ }^{99} \mathrm{Tc}$ content of the dissolver product (the actual value is probably closer to $2 \mathrm{~g} \mathrm{Tc}$ ). ${ }^{10}$ Unfortunately, it was not possible to analyze the undissolved solids from the fuel dissolution experiments as they were inadvertently discarded during clean-up activities subsequent to the solvent extraction work.

Based on the isotopic breakdown of the $\mathrm{Pu}$ isotopes from the radioanalytical results for ${ }^{238} \mathrm{Pu},{ }^{241} \mathrm{Pu}$, and ${ }^{239 / 240} \mathrm{Pu}$, along with the ICP-MS signals at $\mathrm{m} / \mathrm{z}=239$ and 240 , it is possible to compute masses of each $\mathrm{Pu}$ isotope as well as the total $\mathrm{Pu}$ mass. (This method ignores the contribution at $\mathrm{m} / \mathrm{z}=239$ due to other species, such as ${ }^{238} \mathrm{UH}^{+}$, which also contribute to the signal). The computed total mass of $\mathrm{Pu}$ is $7.87 \mathrm{mg}$ (or $8.99 \mu \mathrm{g} / \mathrm{g}_{\text {cladding }}$ ), can be compared to the special nuclear material inventory value (for ${ }^{239-241} \mathrm{Pu}$ ), to test the reasonability of the calculated value. Assuming the partitioning of $\mathrm{Pu}$ to the cladding is similar to that of $U$, the fraction of $U$ partitioned to the cladding may be used, along with the $\mathrm{Pu}$ inventory value, to compute the "estimated" ${ }^{239-241} \mathrm{Pu}$ content in the cladding, 5.67 $\mathrm{mg}$ ( or $6.48 \mu \mathrm{g} / \mathrm{g}_{\text {cladding) }}$ ). Based on this result, it is expected that the ratio $\mathrm{U} /{ }^{239-241} \mathrm{Pu}$ in the cladding should be about 140 . Using the ICP-ES result for $U(0.794 \mathrm{~g})$ and the ${ }^{239-}$ ${ }^{241} \mathrm{Pu}$ result from the radioanalytical results, $7.75 \mathrm{mg}$, the computed $\mathrm{U} /{ }^{239-241} \mathrm{Pu}$ ratio for the cladding is actually about 102 , which is less than expected value of 140 . The reasons for this deviation are not immediately clear, but it is supposed that the assumption that the signal as $\mathrm{m} / \mathrm{z}=239$ and 240 are due only to $\mathrm{Pu}$ species introduced uncertainty into this estimate of the isotopic breakdown of the $\mathrm{Pu}$.

An inconsistency in these results that is worthy of discussion is that related to $\mathrm{Np}$. As was the case with the ICP-MS results, Np was detected in only one sample. This inconsistency may not to be related to the radioanalytical analyses themselves, but could instead be related to the nature of the samples. A more thorough explanation will be presented during the discussion of the SEM results. 


\section{SEM Results}

The objective of these analyses was two-fold. The first objective was to map compositional variations in $\mathrm{Pu}$ and $\mathrm{U}$ content through the bulk of the cladding, from the inside surface, which contacted the fuel meat, to the outside surface which did not contact the meat. It was believed that if the $\mathrm{Pu}$ and $\mathrm{U}$ resided in close proximity to the former fuel meat-cladding interface, it might be possible to chemically polish the outside surfaces of the cladding in an $\mathrm{HNO}_{3} / \mathrm{KF}$ media and leach the actinides from the inside surface of the cladding. The second objective was to perform a microscopic, "visual" inspection of an as-received, cut sample to identify any visually-detectable sample characteristics that could help decipher the analytical data.

The first objective was not attained. It was not possible to map the $\mathrm{U}$ and $\mathrm{Pu}$ composition. The second objective, a microscopic, "visual" inspection of an as-received, cut sample, to identify any visually-detectable sample characteristics that could help decipher the analytical data was successful.

It was not possible to map the compositional variation of $\mathrm{Pu}, \mathrm{U}$, or any other element in the bulk of the material. Inspection of numerous spots on the surface of the sample did, however, reveal information about the samples and possibly the sampling technique. Over the bulk of the material, with very few exceptions, only $\mathrm{Zr}$ was unambiguously identified. The surface texture of the sample was variable. Some of the textural discontinuities are believed to be due to the cutting method. Near the outer periphery of the cross section of cladding that was studied, markings on the cross-sectional face suggested that the samples had been cut by the tube cutting tool. As the surface was viewed across its surface from the outer toward the inner edge, the surface texture changed from the smooth, striated surface to a rougher, bumpy-looking surface that appeared to be a fractured surface.

Other surface discontinuities, especially when viewed in the back-scattered electron mode, showed regions of the cross-sectional surface that were visually and compositionally unique as compared to the bulk of the material. One type of region, which was very large in area (with dimensions in the tens of $\mu \mathrm{m}$ range), was rich in Fe. Other regions, with dimensions in the 1-10 micron range, were essentially pure U. While it was not possible to determine the depth of the Fe-rich regions, which also showed the presence of considerable $\mathrm{Zr}$, the U-rich regions looked like particles of nearly pure $\mathrm{U}$ (or $\mathrm{UO}_{2}$ ) resting on the surface of the sample. No $U$ was detected except in these regions.

No Sn was detected in the bulk of the cladding. The failure to detect Sn was unexpected since the Sn content is above the detection threshold of the technique.

\section{Interpretation of Results}

Taken together, these results can be used to develop insights into interactions between the fuel meat and cladding during irradiation, shortcomings of the $\mathrm{HNO}_{3}$ chop-leach process for removing the fuel meat from Zircaloy-2 cladding, and ways to improve the chopleach process to enhance the efficacy for removal of actinides from the fuel cladding. In 
addition to the information about the cladding material, the results, taken together, can also aid in identification of the analytical techniques best suited to samples of this type.

\section{Analytical Techniques}

Upon review of all of the analytical techniques employed during this study, it was concluded that the radioanalytical techniques, such as ${ }^{99} \mathrm{Tc}$ and $\mathrm{Pu}$ isotopic determinations, are the most reliable. In these techniques, the analyte of interest is often separated from the bulk of the sample and independently determined; however, to employ these techniques in a judicious fashion, basic knowledge about the chemical composition of the samples of interest is required. This basic knowledge is generally acquired by other, less specific, analytical techniques, such as ICP-ES and ICP-MS.

The ICP-ES technique is quite useful for identifying which analytes might be present in the sample of interest, and for a variety of analytes produces straightforward results. The $\mathrm{U}, \mathrm{Zr}, \mathrm{Sn}, \mathrm{Fe}$, and $\mathrm{Cr}$ results appear to be quite reliable; however, the presence of the plethora of $4 \mathrm{~d}, 5 \mathrm{~d}$, actinide, and lanthanide elements in the samples studied during this work made it nearly impossible to reliably determine the composition of some of the dand f-transition elements by this method. An example of this difficulty is the analyte Ag. The quantity of Ag present in the cladding, as predicted by this technique, is about 11 times too high as compared to the silver content predicted by both the ORIGEN2 modeling and ICP-MS results.

The ICP-MS technique was quite useful as both a qualitative and quantitative technique. Qualitatively, it allows the user to look and see if nuclides of interest, such as ${ }^{107} \mathrm{Ag}$, ${ }^{239} \mathrm{Pu}$, or ${ }^{120} \mathrm{Sn}$ could be present in the sample of interest. Used in consort with other information, such as radioanalytical data and ORIGEN2 modeling results, these results can be used to partition $\mathrm{Pu}$ between the 239 and 240 isotopes; however, it must be recognized that more than a single species can be associated with the signal at some $\mathrm{m} / \mathrm{z}$ values. For example, species such as ${ }^{238} \mathrm{UH}^{+}(\mathrm{g})$ can contribute to the signal at $\mathrm{m} / \mathrm{z}=239$, so use of the mass spectral data for the purpose of partitioning the $\mathrm{Pu}$ between the 239 and 240 isotopes is by no means an exact science.

The SEM analyses were extremely useful because they allowed the imaging of the asprepared samples. Without these analyses, it would not have been possible to identify the inhomogeneous distribution of the $U$ detected during the various analyses that addressed only the bulk composition of the cladding.

The ORIGEN2 modeling results, provided by ANL-Chicago personnel, provided a baseline for fission products and actinides contents to which the results of the chemical analyses could be compared. Use of theoretical/computational tools such as this one, in consort with chemical analyses, strengthens the conclusions drawn from the analytical results. 


\section{Fuel/Cladding Chemistry}

Clearly, the chop-leach process, as tested, did not produce a cladding material that is a low-level waste (LLW). The mean actinide content in the cladding samples, $40,000 \eta \mathrm{Ci} / \mathrm{g}_{\text {cladding }}$, is about $400 \mathrm{X}$ too large to meet LLW disposal criteria. The experimental results, however, suggest that the $\mathrm{U}$ and $\mathrm{Pu}$ are not homogeneously distributed throughout the cladding. Instead, the results suggest that the $U$ is present as nodules of material that are not part of the bulk of the material.

The location of the U-rich regions, which appeared to be particles on the surface of the cut sample, can be explained, at least in part, by the processing of the samples. It appears that the nitric acid treatment of the fuel did not completely solubilize the fuel meat. Instead, small particles of spent fuel appear to have remained on the surface after the dissolution process was thought to be complete. It is unlikely that these U-rich particles are the result of dissolution of fuel followed by precipitation of uranyl nitrate, since the cladding from the dissolution experiments in which recrystallization occurred was washed in hot water at the end of the fuel dissolution experiments to ensure that recrystallized uranyl nitrate would be completely solubilized.

The location of the U-rich particles on the cut surface of the samples is consistent with the incomplete dissolution scenario and can be explained by the sample preparation techniques. It would be expected that any undissolved fuel particles remaining on the cladding would be present on the inside circumference of the cladding tubes. Two cuts with a manual tubing cutter (operated remotely using "master-slave" manipulators) were required to section each sample. First, the cladding tube was sectioned into two pieces. This required rotation of the cutter around the outside circumference of the tubing. After each rotation, the pressure on the cutting blade (which is a sharp-edged steel wheel that turns as the cutter body is rotated around the tubing) is increased. After many turns around the outside circumference of the tubing (as many as $20-40$ rotations), the pieces on either side of the cutting edge were severed. The same operation was repeated to remove the narrow rings of cladding samples used to produce the samples that were dissolved and the sample analyzed by SEM. If during the rotation operation, the cutter penetrates the inner surface of the tubing in one spot, material from the inside surface of the sample, where the cutter contacted it, would be transferred to other locations on the cut surface as the cutter blade rotated. This material could be deposited as chunks, especially if the cutter did not pass over the deposited material enough times to smear it over a larger surface of the cut.

The presence of $\mathrm{Pu}$ in the cladding higher than expected concentrations (the fraction of the total $\mathrm{Pu}$ in the cladding is greater than for $\mathrm{U}$ ) is not believed to be an artifact of the sampling technique or analytical methods. It is likely that a fraction of the $\mathrm{Pu}$ and $\mathrm{U}$ dissolve in the Zircaloy cladding while the fuel is in the reactor, forming either a solution or alloy. It is theorized that the $\mathrm{U}$ is more easily leached from the cladding than the $\mathrm{Pu}$, leaving a higher fraction of the $\mathrm{Pu}$ in the cladding.

The presence of the Fe-rich areas is also consistent with the sample preparation method. In this case, however, it is believed that the Fe originated on the cutter wheel. Since the 
wheel passes over the surface multiple times and the Zircaloy is somewhat hard and brittle (during the cutting activity it cracked instead of being cut), it would be expected that the Fe deposits would get smeared over a large surface area of the cut, which is what was observed.

\section{Conclusions}

Based on the available analytical results, and the interpretation of those results, the following conclusions are drawn.

- The chop-leach method, as performed with an initial $4 \mathrm{M} \mathrm{HNO}_{3}$ heel and subsequent additions of $10 \mathrm{M} \mathrm{HNO}_{3}$, was inadequate for complete digestion of the $\mathrm{UO}_{2}$ fuel meat present in the Dresden-1 fuel samples studied. This failure of the dissolution process resulted in cladding samples that contained TRU actinides at about $40,000 \eta \mathrm{Ci} / \mathrm{g}_{\text {cladding, }}$, which is about 400 times more TRU content than is allowable in LLW.

- The ICP-ES method appears to over-estimate the quantities of a variety of elements, such as Ag, Ce, Gd, La, and Sb. It is believed this phenomenon is related to spectral interferences from d-block and f-block elements.

- Future studies should be performed to determine the efficacy of $\mathrm{HNO}_{3} / \mathrm{KF}$ leaching to chemically polish the cladding surface and remove undissolved fuel meat.

- Further analyses of cladding samples, to more thoroughly characterize the nature of the U- and TRU-bearing phases present in the cladding, are recommended.

\section{References}

${ }^{1}$ Blanco, R. E., "Preparation of Power Reactor Fuels for Processing by Solvent Extraction" in Process Chemistry, Volume 2, Progress in Nuclear Energy, Series III, Hyman, H. H., editor, Pergamon Press: New York, pp. 223-246 (1958).

2 Blanco, R. E. and Watson, C. D., "Head-End Processes for Solid Fuels" in Volume II. Fuel Reprocessing, Reactor Handbook, $2^{\text {nd }}$ edition, Stoller, S. M. and Richards, R. B., editors, Interscience Publishers, Inc.: New York, pp. 23-106 (1961).

${ }^{3}$ Slansky, C. M., "Chapter III. Preparation of Fuels for Processing” in Chemical Processing of Reactor Fuels, Nuclear Science and Technology, Academic Press: New York, pp. 75-124 (1961).

${ }^{4}$ Long, J. T., Engineering for Nuclear Fuel Reprocessing, American Nuclear Society, La Grange, IL, pp. 273-326 (1978).

${ }^{5}$ Slansky, C. M., "Chapter III. Preparation of Fuels for Processing" in Chemical Processing of Reactor Fuels, Nuclear Science and Technology, Academic Press: New York, p. 91 (1961).

${ }^{6}$ Kessinger, G. F. and Thompson, M. C., Dissolution of Dresden Reactor Fuel, WSRCTR-2002-00448, Revision 0, Westinghouse Savannah River Company (September 2002).

${ }^{7}$ Discussions held with Alan Bakel, ANL-Chicago, January 7, 2004 and March 15, 2004.

${ }^{8}$ Croff, A. G., Nuclear Technology, Vol. 62, p.335 (1983). 
${ }^{9}$ Kiser, R. W., Introduction to Mass Spectrometry and Its Applications, Prentice Hall Book Co., New York, p. 290 (1965).

${ }^{10}$ Thompson, M. C., Norato, M. A., Kessinger, G. F., Pierce, R. A., Rudisill, T. S., and Johnson, J. D., Demonstration of the UREX Solvent Extraction Process with Dresden Reactor Fuel Solution, WSRC-TR-2002-00444, Revision 0, Westinghouse Savannah River Company (September 2002). 